\title{
Identification of Bcl-6-dependent follicular helper NKT cells that provide cognate help for $B$ cell responses
}

\author{
Pheh-Ping Chang ${ }^{1}$, Patricia Barral ${ }^{2}$, Jessica Fitch ${ }^{1}$, Alvin Pratama ${ }^{1}$, Cindy S Ma ${ }^{3}$, Axel Kallies ${ }^{4}$, \\ Jennifer J Hogan ${ }^{1}$, Vincenzo Cerundolo ${ }^{5}$, Stuart G Tangye ${ }^{3}$, Robert Bittman ${ }^{6}$, Stephen L Nutt ${ }^{4}$, Robert Brink ${ }^{3}$, \\ Dale I Godfrey ${ }^{7}$, Facundo D Batista ${ }^{2} \&$ Carola G Vinuesa ${ }^{1}$
}

\begin{abstract}
Lipid antigens trigger help from natural killer T cells (NKT cells) for B cells, and direct conjugation of lipid agonists to antigen profoundly augments antibody responses. Here we show that in vivo, NKT cells engaged in stable and prolonged cognate interactions with B cells and induced the formation of early germinal centers. Mouse and human NKT cells formed CXCR5+PD-1 ${ }^{\text {hi }}$ follicular helper NKT cells ( $\mathrm{NKT}_{\mathrm{FH}}$ cells), and this process required expression of the transcriptional repressor Bcl-6, signaling via the coreceptor CD28 and interaction with B cells. NKT $\mathrm{FH}_{\mathrm{FH}}$ cells provided direct cognate help to antigen-specific B cells that was dependent on interleukin 21 (IL-21). Unlike T cell-dependent germinal centers, those driven by NKT $_{\mathrm{FH}}$ cells did not generate long-lived plasma cells. Our results demonstrate the existence of a $\mathrm{Bcl}-6$-dependent subset of NKT cells specialized in providing help to B cells.
\end{abstract}

\begin{abstract}
The production of switched antibodies is crucial for protection against most viral and bacterial infections. In the presence of $\mathrm{T}$ cell help, $B$ cells reacting to protein antigens can either differentiate into extrafollicular plasma cells, giving rise to a rapid wave of low-affinity antibody, or grow and differentiate in follicles, giving rise to germinal centers. In germinal centers, somatic hypermutation followed by selection of B cells expressing high-affinity B cell antigen receptors (BCRs) gives rise to affinity-matured memory B cells and long-lived plasma cells ${ }^{1}$. It has emerged that the follicular helper $\mathrm{T}$ cell $\left(\mathrm{T}_{\mathrm{FH}}\right.$ cell) subset of $\mathrm{CD}^{+}{ }^{+} \mathrm{T}$ cells is specialized in the provision of help to B cells and the initiation and maintenance of germinal-center reactions ${ }^{2-4}$. $\mathrm{T}_{\mathrm{FH}}$ cells are distinguished from other helper $\mathrm{T}$ cell subsets by their high expression of the transcriptional repressor Bcl-6 that directs their formation and expression of the follicle-homing chemokine receptor CXCR5. $\mathrm{T}_{\mathrm{FH}}$ cells are further characterized by their high expression of the following molecules important for B cell-T cell interactions: interleukin 21 (IL-21), PD-1, SAP, ICOS and CD40L ${ }^{2-4}$. The natural killer T cell (NKT cell) subset of T cells provides cognate help to antigen-specific B cells, which leads to B cell proliferation and differentiation into antibody-producing cells ${ }^{5-8}$. However, the ability of NKT cells to initiate germinal-center reactions has not been examined, and their relationship with $\mathrm{T}_{\mathrm{FH}}$ cells remains unknown.

NKT cells are glycolipid antigen-reactive T cells restricted to the antigen-presenting molecule CD1d and include several different subtypes. The most commonly studied NKT cells are characterized by an invariant T cell antigen receptor (TCR) $\alpha$-chain ( $\alpha$-chain variable
\end{abstract}

region $14-\alpha$-chain joining region $18\left(\mathrm{~V}_{\alpha} 14 \mathrm{~J}_{\alpha} 18\right)$ in mice, and $\mathrm{V}_{\alpha} 24 \mathrm{~J}_{\alpha} 18$ in humans) combined with a limited array of TCR $\beta$ chains $\left(\mathrm{V}_{\beta} 2, \mathrm{~V}_{\beta} 7, \mathrm{~V}_{\beta} 8.2 \text { in mice, and } \mathrm{V}_{\beta} 11 \text { in humans }\right)^{9}$. These are sometimes referred to as 'invariant NKT cells' or 'type 1 NKT cells', and this subtype (called 'NKT cells' here) is the subject of this investigation. The synthetic mimic of the natural glycolipid $\alpha$-galactosylceramide $(\alpha$-GalCer) is the best-characterized NKT cell-stimulating glycolipid ${ }^{10}$. Several different glycolipid antigens that elicit NKT cell activation have been found in pathogenic bacteria, including Erlichia species, Sphingomonas species and Borrelia burgdorferi ${ }^{11}$. In cognate NKT cell-B cell interactions, B cells have been shown to present to NKT cells, via CD1d molecules, lipid antigens internalized through the BCR, which elicits NKT cell help for antibody responses ${ }^{5,8}$. Such help leads to the formation of large foci of extrafollicular plasma cells, greatly enhancing antibody responses ${ }^{5}$. Although the formation of germinal centers has not been described after the provision of cognate help from NKT cell to B cells, enhancement of memory responses has been observed in the presence of noncognate NKT cell help ${ }^{12}$.

NKT cells are heterogeneous in phenotype and function ${ }^{9}$ and consist of $\mathrm{CD}^{+}$and $\mathrm{CD} 4^{-}$subsets. In humans, $\mathrm{CD} 4^{-}$NKT cells are less able to produce $\mathrm{T}$ helper type $2\left(\mathrm{~T}_{\mathrm{H}} 2\right)$ cytokines $^{13,14}$. Expression of the activating NK cell receptor NK1.1 in C57BL/6 mice also identifies an NKT cell subset that produces less IL- 4 and more interferon- $\gamma$ than does its NK1.1 $1^{-}$counterpart ${ }^{14,15}$. Furthermore, there seem to be subsets of NKT cells specialized in the promotion of $\mathrm{T}_{\mathrm{H}} 2$ cell-mediated immunity ${ }^{16}$ or the production of cytokines associated with immunity

\footnotetext{
${ }^{1}$ Department of Pathogens and Immunity, John Curtin School of Medical Research, Australian National University, Canberra, Australia. ${ }^{2}$ Lymphocyte Interaction Laboratory, London Research Institute, Cancer Research UK, London, UK. ${ }^{3}$ Immunology Program, Garvan Institute of Medical Research, Darlinghurst, Australia. ${ }^{4}$ The Walter and Eliza Hall Institute of Medical Research, Parkville, Australia. ${ }^{5}$ MRC Human Immunology Unit, Weatherall Institute of Molecular Medicine, University of Oxford, Oxford, UK. ${ }^{6}$ Department of Chemistry and Biochemistry, Queens College of The City University of New York, Flushing, New York, USA. ${ }^{7}$ Department of Microbiology and Immunology, University of Melbourne, Parkville, Australia. Correspondence should be addressed to C.G.V. (carola.vinuesa@anu.edu.au).
} 
Figure 1 Dynamics of the provision of help by NKT cells to B cells. (a) Time-lapse imagery of MD4 B cells (pink) interacting with $\mathrm{V}_{\alpha} 14^{+}$ T cells 24-36 h after immunization of mice with particulate HEL- $\alpha$-GalCer Top right corners (white outline), enlargement of cells indicated in main images: MD4 B cells (pink arrowheads), NKT cells (turquoise arrowheads) or conjugate pairs (white arrowheads). Bottom right, MD4 B cell tracks (pink) and NKT cell tracks (turquoise) corresponding to the length of the movie. Bottom right corners, time (minutes:seconds). Scale bar, $20 \mu \mathrm{m}$. (b) Distribution of the duration of contacts between MD4 B cells and NKT cells from mice immunized with particulate $\mathrm{HEL}$ or $\mathrm{HEL}-\alpha-\mathrm{GalCer}$. (c) Speed of individual NKT cells (turquoise filled circles) and MD4 B cells (pink filled circles) and of NKT cells (turquoise open circles) and MD4 $B$ cells (pink open circles) in long-lasting conjugate pairs (conj; $\geq 8 \mathrm{~min}$ ). Each symbol represents an individual cell; small horizontal lines indicate the average. ${ }^{*} P<0.0001$ (two-tailed unpaired Mann-Whitney test).

(d) Distribution of speeds in c. (e) Proliferation of donor HEL-binding cells in the draining popliteal lymph nodes of wild-type mice given CFSE-labeled MD4 B cells and challenged with particles containing $\alpha$-GalCer and/or $\mathrm{HEL}$, assessed by flow cytometry as CFSE dilution $3 \mathrm{~d}$ after immunization. Outlined areas indicate HEL-binding cells. Data are representative of five experiments (a), two (HEL) or five (HEL- $\alpha$-GalCer) experiments (b-d), or three experiments (e).

mediated by IL-17-producing helper $\mathrm{T}$ cells $\left(\mathrm{T}_{\mathrm{H}} 17 \text { cells }\right)^{17,18}$. From a functional point of view, NKT cells have been shown to exert crucial effects on the immune system and to have both pathogenic and immunogenic roles in allergy, allograft rejection, infectious diseases, cancer and autoimmunity ${ }^{19}$. Thus, functionally distinct subpopulations of NKT cells exist that diversify the outcome of responses to lipid-containing antigens.

Given the evidence of the provision of NKT cell help to B cells, we sought to determine whether the specialization program that gives rise to $\mathrm{T}_{\mathrm{FH}}$ cells able to induce potent $\mathrm{B}$ cell differentiation might also be required for NKT cell help. We found follicular helper NKT cells ( $\mathrm{NKT}_{\mathrm{FH}}$ cells) with developmental requirements similar to those of $\mathrm{T}_{\mathrm{FH}}$ cells. These $\mathrm{NKT}_{\mathrm{FH}}$ cells induced the rapid formation of germinal centers in the presence of lipid antigens presented by B cells. We further demonstrated that the formation of these $\mathrm{NKT}_{\mathrm{FH}}$ cells was dependent on factors similar to those required for the development of conventional $\mathrm{T}_{\mathrm{FH}}$ cells: the transcription factor Bcl-6, the coreceptor CD28 and B cell help. Thus, $\mathrm{NKT}_{\mathrm{FH}}$ cells emerge as a distinct subset of NKT cells specialized in the provision of help to $\mathrm{B}$ cells reactive to lipid-containing antigens.

\section{RESULTS}

\section{Dynamics of NKT cell-B cell interactions}

For conventional $\mathrm{T}$ cells, the duration and stability of their interaction with $\mathrm{B}$ cells determines whether differentiation into helper $\mathrm{T}$ cells capable of follicular migration and germinal-center induction occurs. Stable and prolonged B cell-T cell interactions mediated by the adaptor SAP are required for the formation of germinal-center $\mathrm{T}_{\mathrm{FH}}$ cells $^{20}$. Thus, we first set out to determine whether NKT cells can engage in stable cognate interactions with B cells. We used multiphoton microscopy imaging of intact lymph nodes to assess the capacity of NKT cells to form conjugate pairs with antigen-specific B cells in vivo and to understand the spatiotemporal dynamics of those interactions.

The spleens and livers of mice with transgenic expression of $\mathrm{V}_{\alpha} 14$ show enrichment for NKT cells; in these organs, $35-40 \%$ of all cells are positive for $\alpha$-GalCer-loaded tetramer. We labeled NKT cells with the cytosolic dye CFSE and transferred them into wild-type recipient mice together with MD4 B cells (which express a transgenic BCR that recognizes hen egg lysozyme (HEL) with high affinity) labeled with the $\mathrm{pH}$-sensitive dual-emission fluoroprobe SNARF-1. At $16 \mathrm{~h}$ after cell transfer, we immunized mice subcutaneously in the footpad with particulate HEL- $\alpha$-GalCer, which consists of biotinylated HEL a
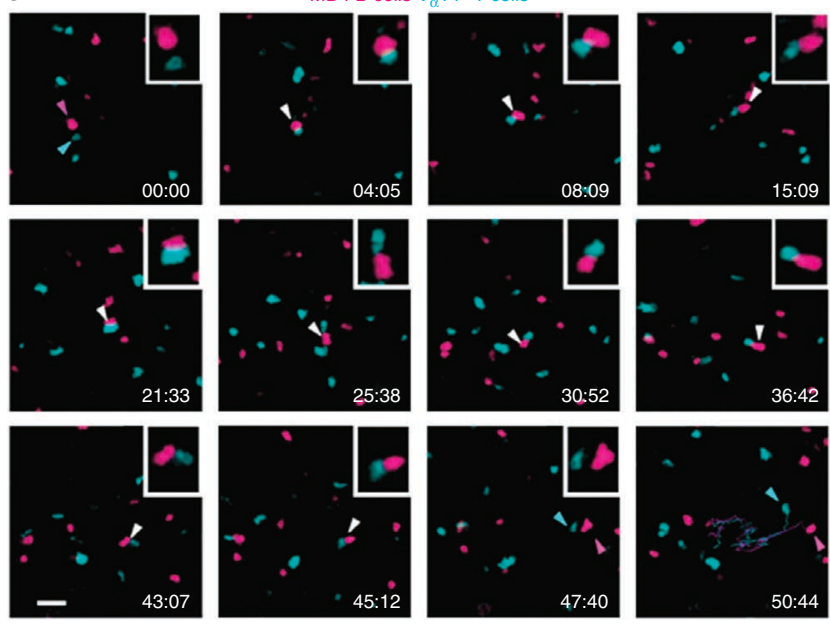

b
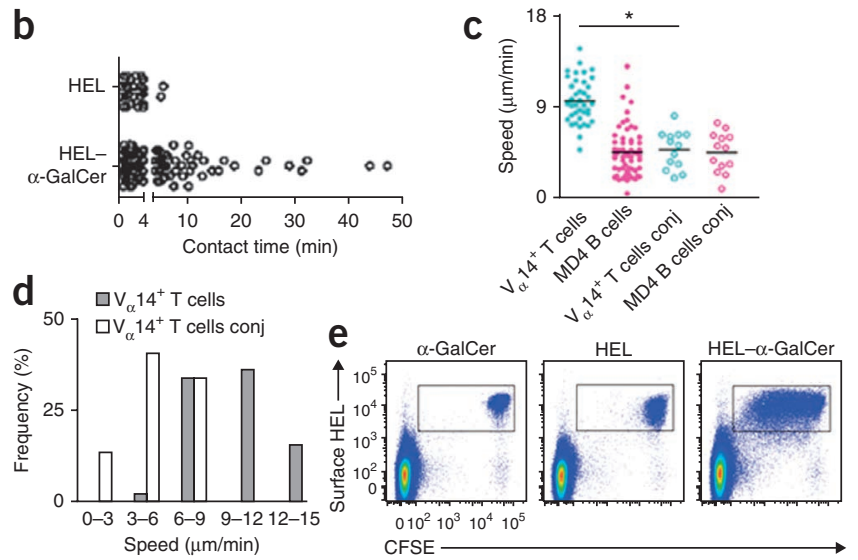

bound through a streptavidin linker to 200-nm silica particles coated with $\alpha$-GalCer ${ }^{5}$, designed to mimic the conditions of infection with bacteria encoding NKT cell agonist ${ }^{21}$. We immunized a control group with particulate HEL. We imaged draining popliteal lymph nodes between 24 and $36 \mathrm{~h}$ after injection of antigen.

After injection of particulate HEL- $\alpha$-GalCer, NKT cells engaged in interactions with MD4 B cells and formed motile conjugate pairs that lasted up to $50 \mathrm{~min}$ (Fig. 1a,b and Supplementary Video 1). These long-lasting interactions were restricted to mice injected with particulate HEL- $\alpha$-GalCer, as after injection of particulate HEL, NKT cells formed only transient contacts with MD4 B cells (92\% of contacts lasted less than 4 min; Fig. 1b). NKT cell-B cell conjugates were highly motile, with B cells always leading the pair (Fig. 1a,c). Those NKT cells engaged in long-lasting conjugate pairs ( $\geq 8 \mathrm{~min}$ ) diminished their speed from $9.6 \mu \mathrm{m} / \mathrm{min}$ (individual cells) to $4.9 \mu \mathrm{m} / \mathrm{min}$ (NKT cells in conjugates) to accommodate that of the B cells $(4.7 \mu \mathrm{m} / \mathrm{min}$; Fig. 1c,d $)$.

We did similar experiments to investigate the effects of NKT cell-B cell interactions on B cell proliferation in vivo. At $3 \mathrm{~d}$ after immunization, CFSE-labeled donor HEL-binding cells that had internalized lipid antigen through their BCR after immunization with HEL- $\alpha$-GalCer had proliferated extensively in the draining popliteal lymph node, as measured by flow cytometry analysis of CFSE dilution (Fig. 1e). Notably, we detected no proliferation after challenge with either particulate $\alpha$-GalCer or HEL alone, as HEL itself is unable to elicit a $\mathrm{T}$ cell-dependent response on the C57BL/6 background ${ }^{22}$. Together these results demonstrated that NKT cells engaged in stable and cognate interactions with B cells, which led to B cell activation. 
a
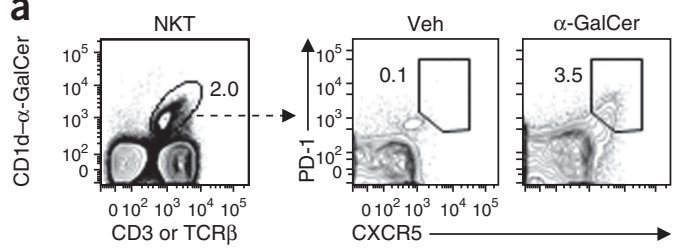

b

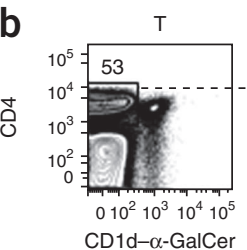

CD1d- $\alpha$-GalCer

C

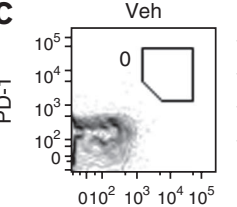

CXCR5

CXCR5

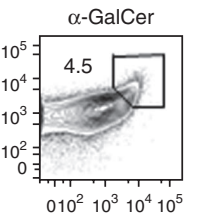

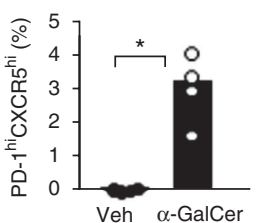
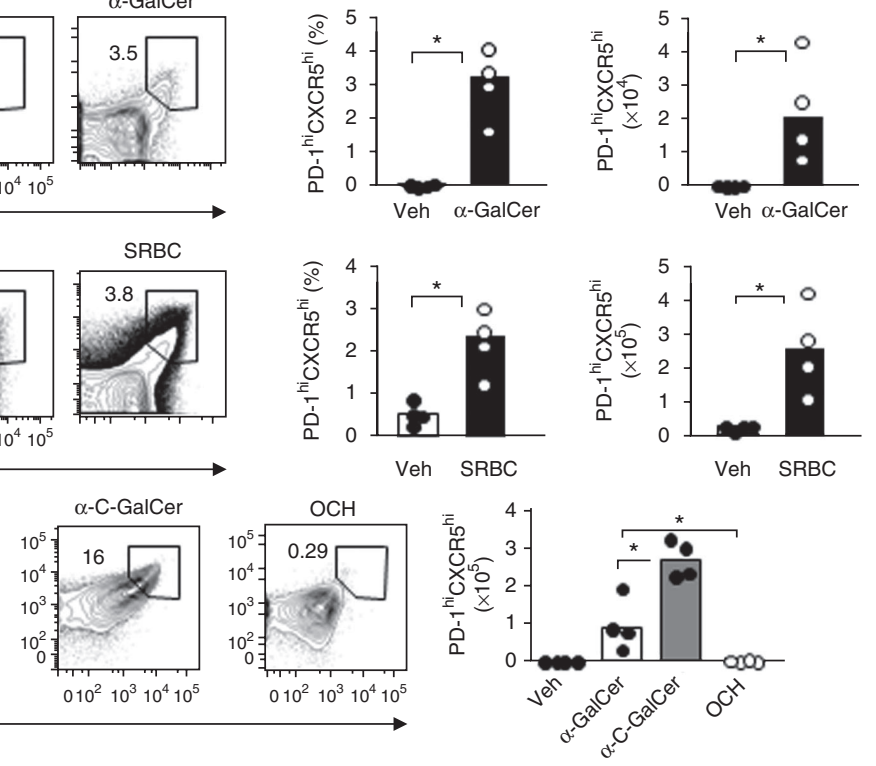

d
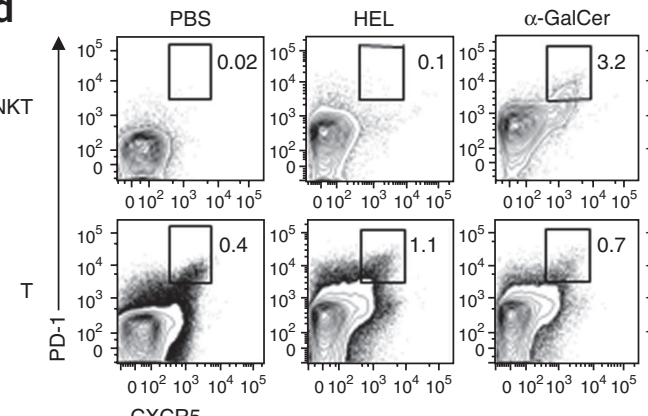

HEL- $\alpha$-GalCe
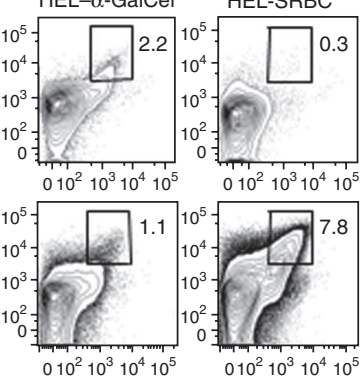

CXCR5

$010^{2} 10^{3} 10^{4} 10^{5}$

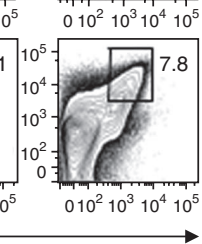

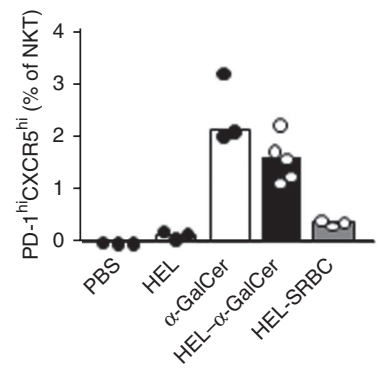

Figure 2 Immunization with $\alpha$-GalCer induces the formation of NKT $T_{F H}$ cells. (a) Flow cytometry of splenic CD1d- $\alpha$-GalCer tetramer-positive CD3 int or TCR int NKT cells (gating, far left) from C57BL/6 mice $6 \mathrm{~d}$ after immunization with vehicle control (Veh; tyloxapol buffer) or $\alpha$-GalCer. (b) Flow cytometry of splenic CD4 ${ }^{+}$CD1d- $\alpha$-GalCer tetramer-negative T cells (gating, far left) from C57BL/ 6 mice $6 \mathrm{~d}$ after injection with vehicle control (PBS) or SRBCs. Numbers adjacent to outlined areas (a,b) indicate percent cells in gate (far left) or NKT FH $_{\text {(PD-1 }}{ }^{\text {hi } C X C R 5} 5^{\text {hi }}$ ) cells (a) or $T_{F H}$ (PD- $1^{\text {hicXCR5 }}$ hi) cells (b). Right (a,b), frequency and absolute number of PD- $1^{\text {hi }} \mathrm{CXCR} 5^{\text {hi }} \mathrm{T}$ cells in the mice at left. (c) Flow cytometry of NKT cells from mice $5 \mathrm{~d}$ after injection

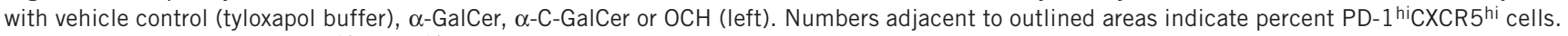
Right, absolute number of PD-1 ${ }^{\text {hi }}$ CXCR5 hi NKT cells in the mice at left. (d) Flow cytometry NKT cells (top) and T cells (bottom) in mice injected with PBS or immunized with particulate HEL, $\alpha$-GalCer, HEL- $\alpha$-GalCer or HEL-SRBC. Numbers adjacent to outlined areas indicate percent PD-1 hiCXCR5 hi cells. Right, frequency of $\mathrm{NKT}_{\mathrm{FH}}$ (PD-1 ${ }^{\text {hi }} \mathrm{CXCR}^{\text {hi }}$ ) cells induced after immunization of the mice at left. (e) Frequency of CD3 ${ }^{\text {int }}$ NKT cells positive for the CD1d- $\alpha$-GalCer tetramer among B220- lymphocytes (top) and PD-1 ${ }^{\text {hi }}$ CXCR5 hi $^{N K T_{F H}}$ cells among NKT cells (bottom) at days $0,3,6$ and 8 after immunization of mice with HEL-SRBC or HEL- $\alpha$-GalCer. Lines join the mean value at each time point for each group. Right (a-d): each symbol represents an individual mouse; bar height indicates the median. NS, not significant. ${ }^{*} P<0.05,{ }^{*} P<0.005$ and $* * * P<0.0005$ (Mann-Whitney U test (a-c) or unpaired $t$ test $(\mathbf{e}))$. Data are representative of four $(\mathbf{a}, \mathbf{c})$ or two $(\mathbf{b}, \mathbf{d})$ independent experiments or one experiment with four mice per group per time point $(\mathbf{e})$.

\section{NKT cells adopt the $\mathrm{T}_{\mathrm{FH}}$ cell phenotype and location}

Stable and prolonged B cell-NKT cell interactions are reminiscent of the SAP-mediated interactions required for the differentiation of $\mathrm{CD}^{+} \mathrm{T}$ cells into $\mathrm{T}_{\mathrm{FH}}$ cells ${ }^{20}$. To investigate the existence of NKT cells with follicular helper characteristics, we immunized mice with $\alpha$-GalCer and $6 \mathrm{~d}$ later assessed by flow cytometry expression of the characteristic $\mathrm{T}_{\mathrm{FH}}$ cell markers CXCR 5 and PD-1 (refs. 3,23 ) by NKT cells identified as being CD $3^{\text {int }}$ or TCR $\beta^{\text {int }}$ and binding to tetramers of $\alpha$-GalCer-loaded CD1d (CD1d- $\alpha$-GalCer; Fig. 2a).

Unimmunized mice or mice that received vehicle only had no detectable CXCR5 $5^{\text {hiPD- }} 1^{\text {hi }}$ cells among TCR $^{+}$cells positive for the CD1d- $\alpha$-GalCer tetramer (Fig. 2a). In mice immunized with $\alpha$-GalCer, however, $3 \%$ of splenic and lymph node NKT cells had high coexpression of CXCR5 and PD- 1 similar to that on CD4 ${ }^{+} \mathrm{T}_{\mathrm{FH}}$ cells negative for the CD1d- $\alpha$-GalCer tetramer induced by immunization with sheep red blood cells (SRBCs; Fig. 2a,b and Supplementary Fig. 1a). We call this subset of TCR $\beta^{+} C X C R 5^{\text {hi }} \mathrm{PD}-1^{\text {hi }}$ cells positive for the CD1d- $\alpha$-GalCer tetramer ' $\mathrm{NKT}_{\mathrm{FH}}$ cells' here.

Stable presentation of antigen on major histocompatibility complex class II by antigen-presenting cells, leading to prolonged TCR stimulation, has been shown to enhance the formation of $\mathrm{T}_{\mathrm{FH}}$ cells ${ }^{24}$. We speculated the same would be true for NKT cells and assessed the formation of $\mathrm{NKT}_{\mathrm{FH}}$ cells in response to two other $\mathrm{NK}$ cell agonists analogs of $\alpha$-GalCer, OCH and C-glycoside ( $\alpha$-C-GalCer), known to differ in their ability to form stable complexes with CD1d. OCH contains a much shorter sphingosine chain that diminishes the stability of binding to CD1d. In contrast, $\alpha$-C-GalCer forms long-lived functional complexes on the surfaces of antigen-presenting cells in $v i v o^{25}$; this functional stability of $\alpha-\mathrm{C}$-GalCer presentation is thought to be due to greater resistance to catabolism ${ }^{25}$. As predicted, $\mathrm{OCH}$ was 
Figure $3 \mathrm{NKT}_{\mathrm{FH}}$ cells localize to germinal centers. Confocal microscopy of frozen spleen sections from CD45.1 $1^{+}$mice given no immunization (no antigen; a) or injected with $\alpha$-GalCer (b) and given adoptive transfer of CD45.2+ NKT cells purified from $\mathrm{V}_{\alpha} 14$-transgenic mice, assessed $3 \mathrm{~d}$ later; sections were stained with immunofluorescence for B220 (green), TCR $\beta$ (red) and CD45.2 (blue; a) or for IgD (turquoise), peanut agglutinin (PNA; red) and CD45.2 (yellow; b). Arrowheads (a) indicate donor-derived TCR $\beta^{+}$CD 45.2 $2^{+}$NKT cells. PALS, periarteriolar lymphoid sheaths; B, B cell; GC, germinal center. Original magnification (a), $\times 40$; scale bars (b),

$20 \mu \mathrm{m}$. Data are representative of two independent experiments.

a very poor inducer of $\mathrm{NKT}_{\mathrm{FH}}$ cells, whereas $\alpha-\mathrm{C}$-GalCer induced threefold more $\mathrm{NKT}_{\mathrm{FH}}$ cells than did $\alpha$-Galcer (Fig. 2c).

We also compared the formation of $\mathrm{T}_{\mathrm{FH}}$ cells and $\mathrm{NKT}_{\mathrm{FH}}$ cells in the context of cognate interactions with a defined population of antigen-specific B cells that internalized either a lipid- or proteincontaining antigen through their BCR. For this, we used CD45.2 $2^{+}$ $\mathrm{SW}_{\mathrm{HEL}} \mathrm{B}$ cells, which bear a rearranged gene encoding a HEL-specific variable-diversity-joining region 'targeted into' the immunoglobulin heavy-chain locus, combined with a HEL-specific $\kappa$-light-chain transgene $^{26}$. We transferred $\mathrm{SW}_{\mathrm{HEL}} \mathrm{B}$ cells intravenously into CD45.1 $1^{+}$ $\mathrm{C} 57 \mathrm{BL} / 6$ mice, then immunized recipient mice with particulate HEL- $\alpha$-GalCer or HEL conjugated to SRBCs (HEL-SRBC), a control immunogen able to stimulate a conventional $\mathrm{T}$ cell-dependent antibody response. Other immunogens we used as additional controls included PBS, particulate HEL and $\alpha$-GalCer.

As expected, we observed the formation of $\mathrm{NKT}_{\mathrm{FH}}$ cells in mice immunized with HEL- $\alpha$-GalCer but not in those immunized with HEL-SRBC, whereas $\mathrm{T}_{\mathrm{FH}}$ cells formed readily after immunization with HEL-SRBC but not after immunization with HEL- $\alpha$-GalCer (Fig. 2d). The total frequency of NKT cells peaked by day 3 in the spleen and decreased thereafter (Fig. 2e), which probably reflected contraction of the activated NKT cell population, as reported before 27,28 . The proportion of $\mathrm{NKT}_{\mathrm{FH}}$ cells among remaining NKT cells peaked on day 6 (Fig. 2e), which suggested 'preferential' retention or survival of this subset in the spleen.

The results above showed that NKT cells were able to adopt a PD- ${ }^{\text {hi }}$ CXCR5 ${ }^{\text {hi }}$ phenotype. In the case of conventional $\mathrm{CD} 4^{+} \mathrm{T}$ cells, scattered $\mathrm{PD}-1^{+} \mathrm{Bcl}-6^{+} \mathrm{T}_{\mathrm{FH}}$ cells are first found in the outer $\mathrm{T}$ cell zones in the spleen and interfollicular areas of lymph nodes; these cells prime $B$ cells to differentiate into either short-lived extrafollicular plasmablasts or germinal-center B cells ${ }^{24,29}$. Clusters of more differentiated PD- $1^{\text {hi }} \mathrm{T}_{\mathrm{FH}}$ cells are later found in germinal centers ${ }^{23}$, and these cells provide selection signals to $B$ cells that have acquired mutations in their immunoglobulin $\mathrm{V}$-region genes. We therefore investigated whether $\mathrm{NKT}_{\mathrm{FH}}$ cells were also present in germinal centers. For this, we purified CD45.2 $2^{+} \mathrm{NKT}$ cells from $\mathrm{V}_{\alpha}$ 14-transgenic mice and transferred the cells into congenic CD $45.1^{+}$recipient mice, which we also immunized with $\alpha$-GalCer $16 \mathrm{~h}$ after adoptive transfer. In the absence of antigen and immunization with $\alpha$-GalCer, we detected NKT cells $\left(\mathrm{CD} 45.2^{+} \mathrm{TCR} \beta^{+} \mathrm{B} 220^{-}\right)$in the spleens of recipient mice mainly in the T cell zones, red pulp and marginal zone of the spleen (Fig. 3a and data not shown). At $3 \mathrm{~d}$ after injection of $\alpha$-GalCer, we found donor-derived PD- $1^{+}$NKT cells inside germinal-center areas that bound peanut agglutinin, consistent with their acquisition of a PD- $1{ }^{\text {hi }} \mathrm{CXCR}^{\mathrm{hi}} \mathrm{NKT}_{\mathrm{FH}}$ cell phenotype (Fig. 3b and Supplementary Fig. 1b). These results suggested that $\mathrm{NKT}_{\mathrm{FH}}$ and $\mathrm{T}_{\mathrm{FH}}$ cells share both phenotype and location.

Phenotypic characterization of mouse and human $\mathrm{NKT}_{\mathrm{FH}}$ cells Over $80 \%$ of $\mathrm{NKT}_{\mathrm{FH}}$ cells expressed CD4, compared with only $30 \%$ of non- $\mathrm{NKT}_{\mathrm{FH}}$ cells (Fig. 4a). Conversely, less than $10 \%$ of $\mathrm{NKT}_{\mathrm{FH}}$ cells expressed NK1.1, compared with over $50 \%$ of non- $\mathrm{NKT}_{\mathrm{FH}} \mathrm{NKT}$ a

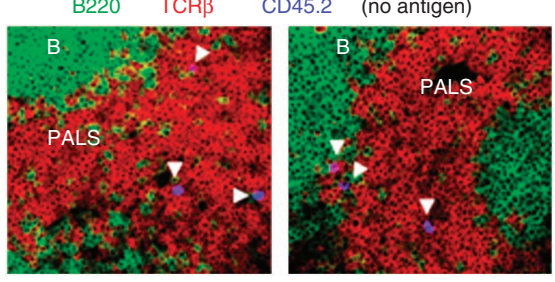

b
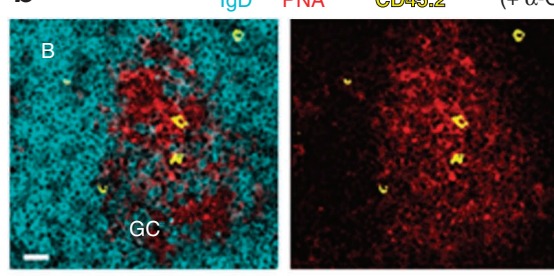

$+\alpha$-GalCer)
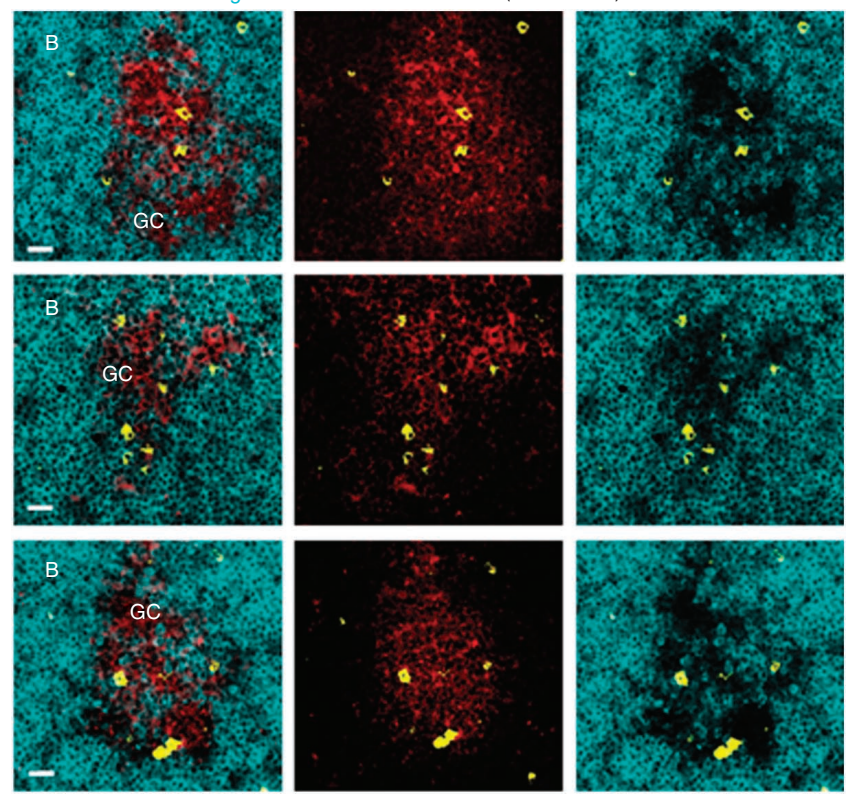

cells (Fig. 4a). That finding may reflect the downregulation of NK1.1 expression that follows NKT cell activation ${ }^{27,28}$, although it seems to have influenced $\mathrm{NKT}_{\mathrm{FH}}$ cells more than other NKT cells. As shown for conventional $\mathrm{T}_{\mathrm{FH}}$ cells ${ }^{30}, \mathrm{NKT}_{\mathrm{FH}}$ cells also downregulated CD127 (IL-7 receptor- $\alpha$; Fig. 4b) and upregulated the inhibitory receptor CD272 (BTLA) as well as Bcl-6 (Fig. 4c).

Next we sought to determine whether the subset of $\mathrm{NKT}_{\mathrm{FH}}$ cells newly identified in mice also existed in humans. To do this, we examined human tonsils obtained after routine tonsillectomy. We identified human NKT cells by their expression of the canonical TCR $\mathrm{V}_{\alpha} 24$ and $\mathrm{V}_{\beta} 11$ chains. Around $10 \%$ of human NKT cells had high coexpression of CXCR5 and PD-1. As with human $\mathrm{T}_{\mathrm{FH}}$ cells $^{30}, \mathrm{~V}_{\alpha} 24^{+}$CXCR5 $5^{\text {hi }}$ $\mathrm{NKT}_{\mathrm{FH}}$ cells also had the highest expression of BTLA, and a proportion of these coexpressed the highly glycosylated antigen CD57 (Fig. 4d).

Shared requirements for the development of $\mathrm{NKT}_{\mathrm{FH}}$ and $\mathrm{T}_{\mathrm{FH}}$ cells Bcl-6 has been shown to direct the development of $\mathrm{T}_{\mathrm{FH}}$ cells, inducing the upregulation of PD-1, ICOS and the chemokine receptors CXCR4 and CXCR5 while downregulating CCR7 (ref. 3). To investigate whether Bcl-6 expression was also required for the formation of $\mathrm{NKT}_{\mathrm{FH}}$ cells, we generated mixed fetal liver chimeras in which only NKT cells lacked Bcl-6. As expected, Sh2d1 $a^{-1-}$ hematopoietic cells, which are deficient in SAP expression, failed to generate NKT cells ${ }^{31}$ (Supplementary Fig. 2a). We irradiated mice deficient in recombination-activating gene 1 and reconstituted them with a 50:50 mixture of $\mathrm{Bcl6}^{-1-}$ fetal liver cells and Sh2 $\mathrm{d} 1 \mathrm{a}^{-/-}$bone marrow-derived hematopoietic stem cells or a control 50:50 mixture of $\mathrm{Bcl}^{+/+}$fetal liver cells and $S h 2 d 1 a^{-/-}$bone marrow-derived hematopoietic stem cells. In these chimeras, the Sh2d1 $a^{-/-}$hematopoietic cells help to keep mice healthy; reconstitution with $100 \% \mathrm{Bcl}^{-1-}$ hematopoietic 
a
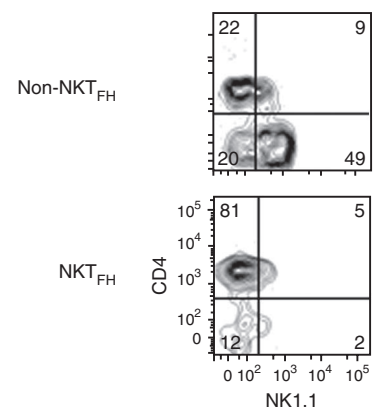

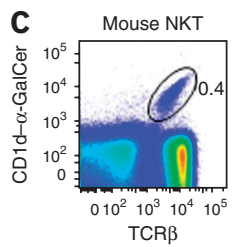

TCR $\beta$

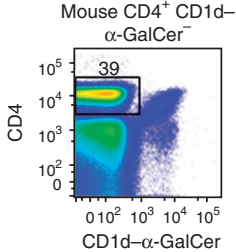

b
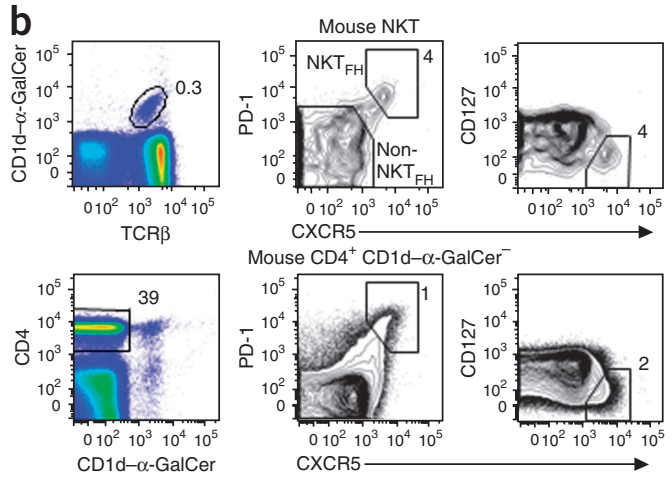
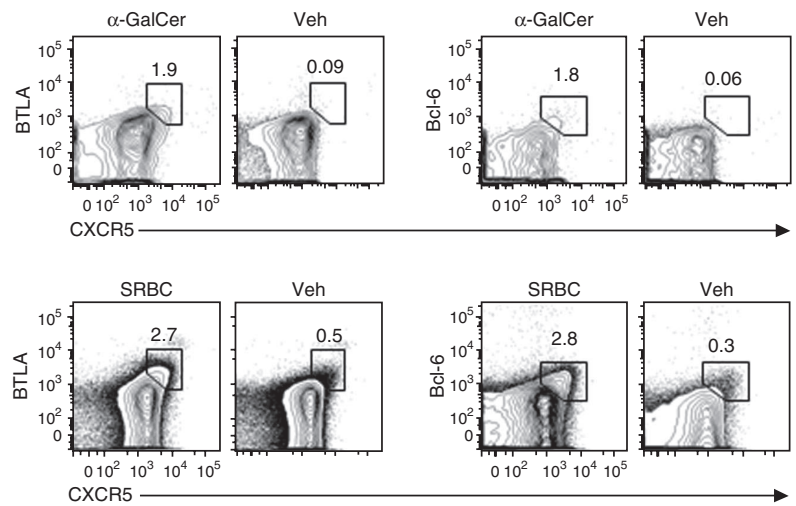

d
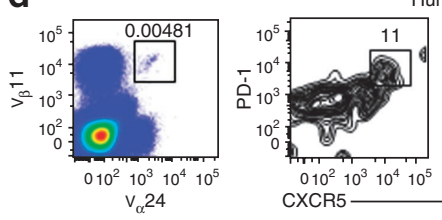

Human NKT
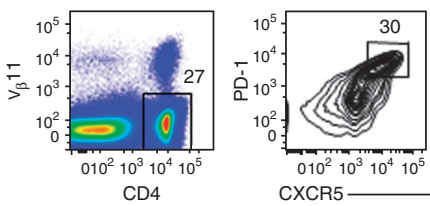

Human $\mathrm{CD}^{+} \mathrm{V}_{\beta} 11$
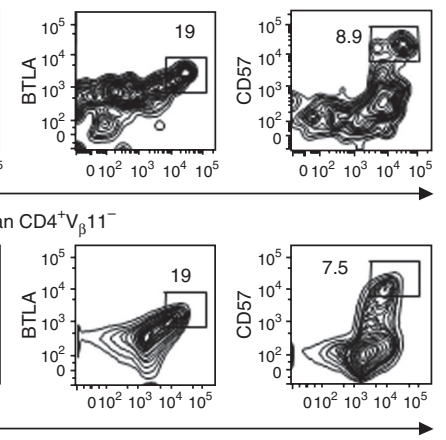

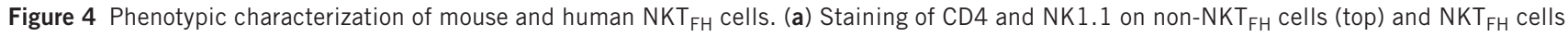
(bottom) from mice immunized $5 \mathrm{~d}$ before with $\alpha$-GalCer. (b) Flow cytometry of cells from spleens collected $5 \mathrm{~d}$ after intraperitoneal immunization of mice with $\alpha$-GalCer. Top row, NKT cell gate (TCR int CD1d- $\alpha$-GalCer tetramer-positive; left) used to identify non-NKT ${ }_{F H}$ cells (PD-1 ${ }^{\text {lo } C X C R 5-) ~ a n d ~} \mathrm{NKT}_{\mathrm{FH}}$ cells (PD- ${ }^{\text {hi }}{ }^{\text {CXCR5 }}{ }^{\text {hi }}$; top middle) stained for CD127 versus CXCR5 (right). Bottom row, T cell gate (CD4 ${ }^{+}$CD1d- $\alpha$-GalCer tetramer-negative; left) used to gate $T_{F H}$ cells (PD- $1^{\text {hi }} \mathrm{CXCR} 5$ hi ; middle) stained as above (right). (c) Flow cytometry of cells from spleens collected $6 \mathrm{~d}$ after intraperitoneal injection of mice with PBS buffer (vehicle), $\alpha$-GalCer or SRBCs, showing the NKT cell gate (TCR int and CD1d- $\alpha$-GalCer tetramer-positive; top far left) or T cell gate (CD4 ${ }^{+}$CD1d- $\alpha$-GalCer tetramer-negative; bottom far left), and staining for BTLA or Bcl- 6 versus CXCR5 (right). (d) Flow cytometry of human tonsil NKT cells $\left(\mathrm{V}_{\beta} 11^{+} \mathrm{V}_{\alpha} 24^{+}\right.$; top left) and $\mathrm{CD} 4^{+} \mathrm{V}_{\beta} 11^{-}$cells (bottom left), assessing expression of PD-1, BTLA, CD57 versus CXCR5. Numbers adjacent to outlined areas indicate percent cells in each throughout. Data are representative of three $(\mathbf{a})$ or two $(\mathbf{b}, \mathbf{c})$ independent experiments or three experiments with a total of four human tonsils (d).

cells leads to the inflammatory disease seen in $B c l 6^{-1-}$ mice $^{32}$. Also, Sh $2 d 1 a^{-/-}$stem cells give rise to Bcl-6-sufficient B cells able to generate germinal centers. In all chimeras, all NKT cells derived exclusively from the $\mathrm{Bcl6}^{-/-}$or $\mathrm{Bcl}^{+/+}$fetal livers. We injected the chimeric mice with particulate $\alpha$-GalCer. In the absence of Bcl-6expressing NKT cells, there was a complete absence of $\mathrm{NKT}_{\mathrm{FH}}$ cell formation (Fig. 5a). These results demonstrated that Bcl-6 expression was essential for the development of $\mathrm{NKT}_{\mathrm{FH}}$ cells.

The development of $\mathrm{T}_{\mathrm{FH}}$ cells is critically dependent on CD28mediated costimulation ${ }^{33}$. Although the absence of $\mathrm{CD} 28$ or its ligands has been reported to result in less development of NKT cells in the thymus ${ }^{34}$ and to diminish NKT cell proliferative expansion in the periphery ${ }^{35}$, NKT cells were present in similar numbers in the spleens of C57BL/6 Cd28 $8^{-/-}$and $\mathrm{Cd} 28^{+/+}$mice (Supplementary Fig. 2b). To investigate whether CD28-mediated costimulation was required for the formation of $\mathrm{NKT}_{\mathrm{FH}}$ cells, we immunized $\mathrm{Cd} 28^{-/-}$ mice with $\alpha$-GalCer and counted $\mathrm{NKT}_{\mathrm{FH}}$ cells $6 \mathrm{~d}$ later. As reported for $\mathrm{T}_{\mathrm{FH}}$ cells $^{33}, \mathrm{NKT}_{\mathrm{FH}}$ cells did not form in mice that lacked $\mathrm{CD} 28$ signaling (Fig. 5b).

IL-21 is produced in large amounts by $\mathrm{T}_{\mathrm{FH}}$ cells ${ }^{3}$ and an NK1.1 $1^{-}$ subset of NKT cells ${ }^{17}$. Signaling via IL-21 receptor has been shown to have a modest to considerable effect on the formation of $\mathrm{T}_{\mathrm{FH}}$ cells, depending on the immunization strategy ${ }^{3}$. To investigate whether IL-21 was important for the formation or homeostasis of $\mathrm{NKT}_{\mathrm{FH}}$ cells, we assessed $I l 21^{-1-}$ mice and found that unlike the homeostasis of $\mathrm{T}_{\mathrm{FH}}$ cells (Supplementary Fig. 2c), the formation of $\mathrm{NKT}_{\mathrm{FH}}$ cells after immunization with $\alpha$-GalCer was not impaired in the absence of IL-21 (Fig. 5c). This suggested that IL-21 was not essential for $\mathrm{NKT}_{\mathrm{FH}}$ cell formation.

Interactions between $\mathrm{B}$ cells and primed $\mathrm{T}$ cells have also been shown to be important for the maturation of $\mathrm{T}_{\mathrm{FH}}$ cells; in the absence of $\mathrm{B}$ cells, $\mathrm{T}_{\mathrm{FH}}$ cells are not maintained unless antigen presentation is enhanced ${ }^{3}$. To determine whether $\mathrm{NKT}_{\mathrm{FH}}$ cells would form in mice lacking B cells, we studied mice with a loss of function in CD79 $\alpha$ that leads to a complete block in B cell development ${ }^{36}$. We immunized these mice with $\alpha$-GalCer and found that, as shown for $\mathrm{T}_{\mathrm{FH}}$ cells, the production of $\mathrm{NKT}_{\mathrm{FH}}$ cells was almost completely abrogated in the absence of B cells (Fig. 5d).

\section{Cognate help from $\mathrm{NKT}_{\mathrm{FH}}$ cells induces germinal centers}

The acquisition of a PD- $1^{\text {hi }}$ CXCR $5{ }^{\text {hi }}$ phenotype by $\mathrm{CD} 4^{+} \mathrm{T}$ cells is associated with their ability to initiate germinal-center reactions ${ }^{30}$. To investigate antigen-specific germinal-center formation in response to lipid-containing antigens, we transferred $\mathrm{CD} 45.2^{+} \mathrm{SW}_{\mathrm{HEL}} \mathrm{B}$ cells intravenously into $\mathrm{CD} 45.1^{+} \mathrm{C} 57 \mathrm{BL} / 6$ mice. $\mathrm{SW}_{\mathrm{HEL}} \mathrm{B}$ cells can undergo class switching and develop into both germinal-center B cells and extrafollicular plasmablasts in response to $\mathrm{HEL}^{26}$. We immunized recipient mice with either particulate HEL- $\alpha$-GalCer or HEL-SRBC. 
Figure 5 The formation of $\mathrm{NKT}_{\mathrm{FH}}$ cells requires $\mathrm{Bcl}-6$ and signaling via CD28 and B cell help. (a) Gating strategy and staining (left) and frequency and absolute number (far right) of $\mathrm{NKT}_{\mathrm{FH}}$ cells (PD-1 ${ }^{\text {hi }} \mathrm{CXCR} 5^{\text {hi }}$ ) from mixed $\mathrm{BC} / 6^{+/+}$ Sh2d1a ${ }^{-/-}\left(\mathrm{BC} 6^{+/+}\right.$or $\left.+/+\right)$or $\mathrm{Bcl} 6^{-/-} \mathrm{Sh} 2 \mathrm{~d} 1 \mathrm{a}^{-/-}$ $\left(B C / 6^{-1-}\right.$ or $\left.-/-\right)$ chimeric mice $5 \mathrm{~d}$ after immunization with $\alpha$-GalCer or vehicle control. (b-d) Gating strategy and staining (left) and frequency and absolute number (far right) of $\mathrm{NKT}_{\mathrm{FH}}$ cells (PD- $1^{\text {hi }} \mathrm{CXCR} 5^{\text {hi }}$ ) from $\mathrm{Cd} 28^{+/+}$or $\mathrm{Cd} 28^{-/-}$mice (b), $1121^{+/+}$or $1121^{-/-}$mice (c), or

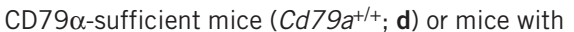
loss of CD79 $\alpha$ function (Cd79am1Anu/m1Anu; $\mathbf{d}$ ), assessed $6 \mathrm{~d}$ after injection of mice with $\alpha$-GalCer or vehicle control. Far right (a-d): each symbol represents an individual mouse; bar height indicates the median. ${ }^{*} P<0.05$ and ${ }^{* *} P<0.005$ (paired $t$-test (a) or Mann-Whitney U-test (b-d)). Data are representative of two independent experiments with four to five mice per group.

Then, $5 \mathrm{~d}$ after immunization, we identified donor-derived germinal-center $\mathrm{B}$ cells by flow cytometry as $\mathrm{CD} 45.2^{+} \mathrm{B} 220^{+} \mathrm{GL}-7^{+} \mathrm{Fas}^{+}$cells with abundant binding of HEL (Fig. 6a). $\mathrm{SW}_{\mathrm{HEL}} \mathrm{B}$ cells had formed germinal centers in all mice immunized with either HEL- $\alpha$ GalCer or HEL-SRBC but not in mice immunized with particles coated with HEL only or $\alpha$-GalCer only (Fig. 6a).

Given reports showing that $\alpha$-GalCer can enhance the response of $\mathrm{B}$ cells lacking CD1d expression $^{12}$, thus in a noncognate way, we investigated whether $\mathrm{SW}_{\mathrm{HEL}} \mathrm{B}$ cell-derived germinal centers were the result of cognate interaction between NKT cells and B cells. For this, we crossed SW $\mathrm{HEL}_{\mathrm{HEL}}$ mice with CD1ddeficient mice and evaluated the response of adoptively transferred $C d 1 d^{-/-} \mathrm{SW}_{\mathrm{HEL}} \mathrm{B}$ cells. HEL-specific germinal centers were absent in recipients of $C d 1 d^{-1-} \mathrm{SW}_{\mathrm{HEL}} \mathrm{B}$ cells (Fig. $\mathbf{6 b}$ and Supplementary Fig. 3a), which confirmed that BCR-mediated uptake of HEL- $\alpha$-GalCer and direct presentation of particulate lipid antigens to NKT cells was required for germinal-center formation. The formation of $\mathrm{NKT}_{\mathrm{FH}}$ cells did not require expression of

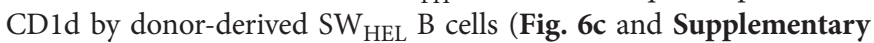
Fig. 3b), which suggested that endogenous CD1d-sufficient antigenpresenting cells were able to provide the necessary signals.

\section{Help from $\mathrm{NKT}_{\mathrm{FH}}$ cells is dependent on IL-21}

IL-21 produced by $\mathrm{T}_{\mathrm{FH}}$ cells is critical not only for maximal formation of follicular and extrafollicular antibody responses but also for germinal-center maintenance ${ }^{3}$. To investigate whether IL-21 is also an important helper cytokine in $\mathrm{NKT}_{\mathrm{FH}}$ cell-mediated induction of germinal centers, we transferred $\mathrm{SW}_{\mathrm{HEL}} \mathrm{B}$ cells lacking the IL-21 receptor into congenic CD $45.1^{+} \mathrm{C} 57 \mathrm{BL} / 6$ mice and injected recipients with HEL- $\alpha$-GalCer. There were $50 \%$ as many HEL-specific germinal-center B cells and plasmablasts in the absence of signaling via the IL-21 receptor (Fig. 6d and Supplementary Fig. 4).

To determine whether $\mathrm{NKT}_{\mathrm{FH}}$ cells were able to produce IL-21, we used reporter mice with sequence encoding green fluorescent protein inserted into the gene encoding IL-21. We immunized the reporter mice with the hapten NP (4-hydroxy-3-nitrophenylacetyl) linked to
$\alpha$-GalCer (NP- $\alpha$-GalCer) and assessed IL-21 production. We found that $10 \%$ of $\mathrm{NKT}_{\mathrm{FH}}\left(\mathrm{CXCR} 5^{\text {hi }}\right.$ cells) produced IL- 21 by day 5 , and this proportion increased slightly (13\%) by day 14 (Fig. 6e). These results established a role for IL-21 signaling in $\mathrm{NKT}_{\mathrm{FH}}$ cell-mediated germinal-center responses.

Next we investigated the kinetics and output of NKT cell-driven antibody responses and compared them with a conventional T celldependent antibody response. For this, we immunized mice with either particulate NP- $\alpha$-GalCer or alum-precipitated particulate NP coupled to ovalbumin (NP-OVA), administered with formalininactivated Bordatella pertussis (Fig. 7a). Antigen-specific germinal centers were already visible by day 3 after immunization with NP- $\alpha$ GalCer but not after immunization with NP-OVA. However, by day 10 , there were nine times as many NP-specific germinal-center B cells in mice immunized with NP-OVA than in those immunized with NP- $\alpha$ GalCer (Fig. 7b). This result correlated with tenfold more total $\mathrm{T}_{\mathrm{FH}}$ cells than $\mathrm{NKT}_{\mathrm{FH}}$ cells at this time point in the spleens of immunized mice (data not shown). There were only slightly more NP-specific germinal-center B cells after day 3 in the response to NP- $\alpha$-GalCer.

Although the immunoglobulin $\mathrm{M}$ (IgM) antibody responses and low-affinity IgG antibody responses (binding to $\mathrm{NP}_{23}$-BSA 
a

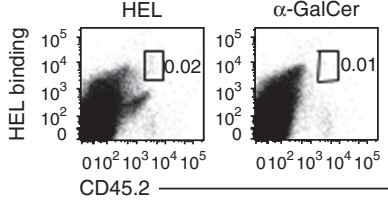

CD45.1 $4 \begin{gathered}10^{5} \\ 10^{4} \\ 10^{3} \\ 10^{2} \\ 0\end{gathered}$

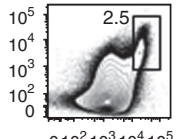

CD45.2 $\begin{gathered}10^{5} \\ \frac{1}{1} 10^{4} \\ \text { ज. } 10^{2}\end{gathered}$

Fas
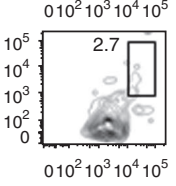
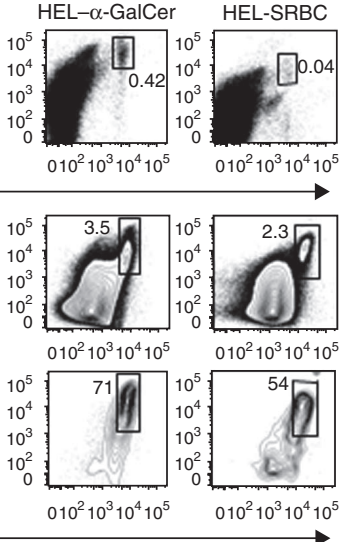

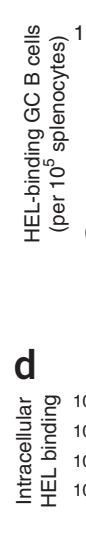

b

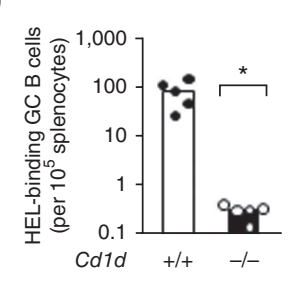

C

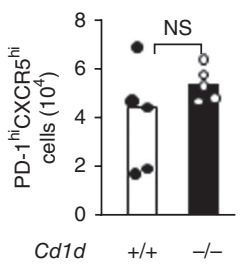

Figure 6 The formation of SW $\mathrm{HEL}_{\mathrm{H}} \mathrm{B}$ cell-derived germinal centers as the result of cognate NKT cell-B cell interaction requiressignalin via the IL-21 receptor. (a) Flow cytometry (left) of splenocytes from CD45.1+ C57BL/6 recipient mice given adoptive transfer of CD45.2+ SW $2_{H E L} B$ cells and immunized with particles containing HEL, $\alpha$-GalCer, HEL- $\alpha$-GalCer or HEL-SRBC, analyzed on day 5 after transfer, showing the gates used to identify donor $\mathrm{B}$ cells in recipient mice (top) and germinal-center B cells (GL-7+Fas ${ }^{+}$)

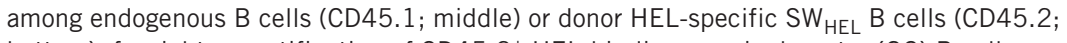
bottom); far right, quantification of CD45.2+ HEL-binding germinal-center (GC) B cells. (b) HEL-binding germinal-center B cells derived from donor $\mathrm{Cd} 1 \mathrm{~d}^{+/+}$or $\mathrm{Cd} 1 d^{-/} \mathrm{SW}_{\mathrm{HEL}}$ $\left(\right.$ CD45.2+ $\left.{ }^{+}\right) \mathrm{B}$ cells, assessed $5 \mathrm{~d}$ after adoptive transfer into C57BL/6 recipient mice immunized with HEL- $\alpha$-GalCer. (c) $\mathrm{NKT}_{\mathrm{FH}}$ cells (PD- $1^{\text {hi }} \mathrm{CXCR} 5^{\text {hi }}$ ) from the mice in $\mathbf{b}$. (d) Gating strategy (left) for extrafollicular plasmablasts (EFPB) and germinal-center B cells derived from donor CD45.2 ${ }^{+} \mathrm{SW}_{\mathrm{HEL}} \mathrm{B}$ cells from mice with intact $\left(/ / 21 r^{+/+}\right)$or deficient $\left(/ / 21 r^{-/-}\right)$signaling via the IL-21 receptor, assessed $5 \mathrm{~d}$ after adoptive transfer into CD45. $1^{+}$recipient C57BL/6 mice immunized with $\mathrm{HEL}-\alpha$-GalCer; right, frequency of $/ 121 r^{+/+}$or $1 / 21 r^{-1-C D 45.2^{+}} \mathrm{SW}_{\mathrm{HEL}} \mathrm{B}$ cell-derived EFPB and germinal-center in the spleens of recipient mice. (e) Flow cytometry of CXCR5 $5^{\text {hi }}$ GFP ${ }^{+}$NKT cells from wild-type mice $\left(/ / 21^{+/+}\right)$or reporter mice with sequence encoding green fluorescent protein in the gene encoding IL-21 (//21 gfp/+), assessed $5 \mathrm{~d}$ or $14 \mathrm{~d}$ after injection of PBS or NP- $\alpha$-GalCer. Far right (a-d): each symbol represents an individual mouse; bar height indicates the median. ${ }^{*} P<0.005$ (Mann-Whitney U-test). Data are representative of two independent experiments (a), one experiment with five mice per group (b-d) or two independent experiments with three to four mice per group (e).

(BSA conjugated to 23 moieties of NP)) to both NP- $\alpha$-GalCer and NPOVA were similar on day 10, the titers of high-affinity IgG antibodies (binding to $\mathrm{NP}_{2}$-BSA) measured on day 28 were higher in the response to NP-OVA (Fig. 7c). Although it was very modest, we observed some affinity maturation at this time point in the NP- $\alpha$-GalCer response (Fig. 7c). Consistent with the limited growth of NKT cell-dependent germinal centers, we did not detect long-lived plasma cells in the bone marrow (Fig. 7d). The difference in the number of switched memory B cells in the spleens of these groups on day 28 was not statistically significant (Fig. 7e), although the trend suggested impaired formation of memory B cells in the response to NP- $\alpha-$ GalCer.

\section{DISCUSSION}

Here we have described a previously unknown subset of NKT cells that shared phenotypic, functional and developmental requirements with conventional $\mathrm{CD} 4^{+} \mathrm{T}_{\mathrm{FH}}$ cells. $\mathrm{NKT}_{\mathrm{FH}}$ cells provided cognate help to B cells that internalized lipid antigens through their BCR, inducing antibody responses to lipid-containing antigens. In mice, the differentiation of $\mathrm{CD}^{+} \mathrm{T}$ cells into $\mathrm{T}_{\mathrm{FH}}$ cells requires $\mathrm{Bcl}-6$, which is responsible for the upregulation of CXCR5 and PD-1 (ref. 3). Our data have demonstrated that Bcl- 6 was also the transcriptional regulator of $\mathrm{NKT}_{\mathrm{FH}}$ cells. This adds to published evidence showing that the transcription factors that drive the differentiation of $\mathrm{CD} 4{ }^{+}$helper $\mathrm{T}$ cells into $\mathrm{T}_{\mathrm{H}} 1$ cells (T-bet), $\mathrm{T}_{\mathrm{H}} 2$ cells (GATA- 3 ) and $\mathrm{T}_{\mathrm{H}} 17$ cells (ROR $\gamma \mathrm{t}$ ) also influence the maturation of NKT cells and production of $\mathrm{T}_{\mathrm{H}} 1-, \mathrm{T}_{\mathrm{H}} 2$ - and $\mathrm{T}_{\mathrm{H}} 17$-associated cytokines, respectively ${ }^{37-42}$. Thus, NKT cells and CD4 ${ }^{+} \mathrm{T}$ cells seem to coopt the same transcription factors and differentiation pathways, thereby generating specialized cell subsets able to migrate into the correct microenvironments and allowing production of the cytokine profile best suited for combating a specific type of pathogen. Our study has also shown that CD28 was required for the formation of $\mathrm{NKT}_{\mathrm{FH}}$ cells. For NKT cells, CD28 signaling is required for their proliferative expansion ${ }^{35}$, which raises the possibility that $\mathrm{CD} 28$ is required for the population expansion of $\mathrm{NKT}_{\mathrm{FH}}$ cells.

NKT cells initiate germinal-center reactions faster than conventional T cells do. The kinetics of NKT cell-dependent germinal centers are similar to those described for $\mathrm{T}$ cell-independent germinalcenter responses and responses in carrier-primed mice in which preexisting primed $\mathrm{T}$ cells are readily available to provide help to $\mathrm{B}$ cells ${ }^{43}$. This may not be unexpected, given the known ability of NKT cells to secrete vast amounts of cytokines soon after antigen encounter ${ }^{9}$. It is also possible that the accelerated response of NKT cells is due at least in part to the greater frequency of precursors reactive to the immunizing lipid than of $\mathrm{T}$ cells with a defined antigen specificity.

Our data showing that expression of CD1d by antigen-specific $\mathrm{B}$ cells that received cognate help from $\mathrm{NKT}_{\mathrm{FH}}$ cells was not required for the formation of $\mathrm{NKT}_{\mathrm{FH}}$ cells suggested that the priming of NKT cells for the formation of $\mathrm{NKT}_{\mathrm{FH}}$ cells occurred before provision of help to $\mathrm{B}$ cells, during interaction with dendritic cells, as shown for $\mathrm{T}_{\mathrm{FH}}$ cells. As is also the case for $\mathrm{T}_{\mathrm{FH}}$ cells, we found that $\mathrm{NKT}_{\mathrm{FH}}$ cells engaged in long-lasting interactions with $\mathrm{B}$ cells. Prolonged interactions between $\mathrm{T}_{\mathrm{FH}}$ cells and $\mathrm{B}$ cells required for terminal differentiation into $\mathrm{T}_{\mathrm{FH}}$ cells and follicular entry have been shown to be SAP dependent ${ }^{20,44}$. SAP signaling is also probably required for terminal differentiation into $\mathrm{NKT}_{\mathrm{FH}}$ cells. Given the similarities 
a

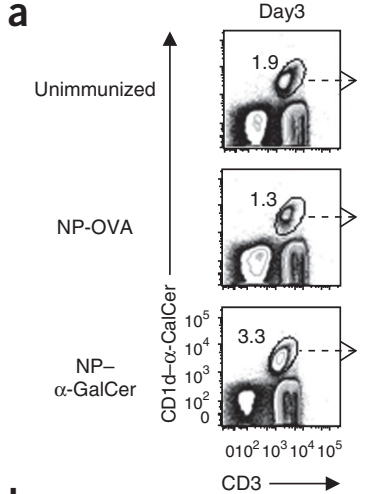

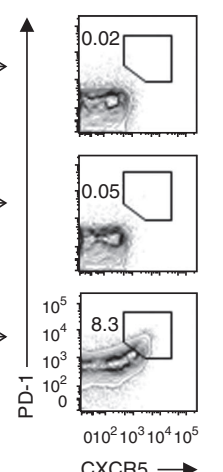

$\mathrm{CXCR} 5 \longrightarrow$

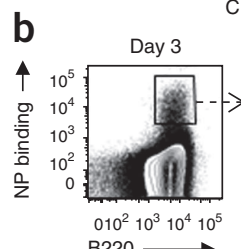

$\mathrm{B} 220 \longrightarrow$ G NP-OVA

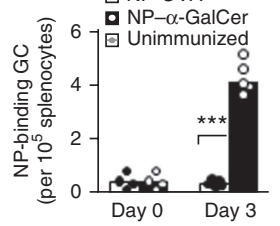

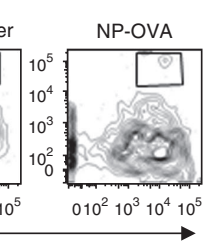
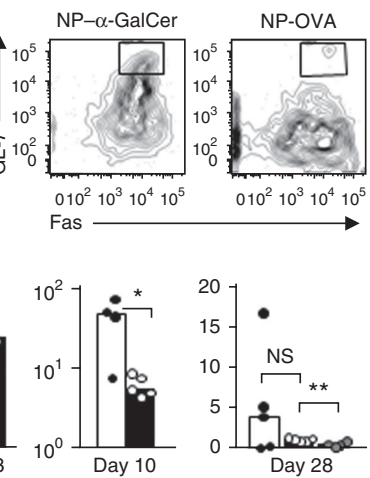

C
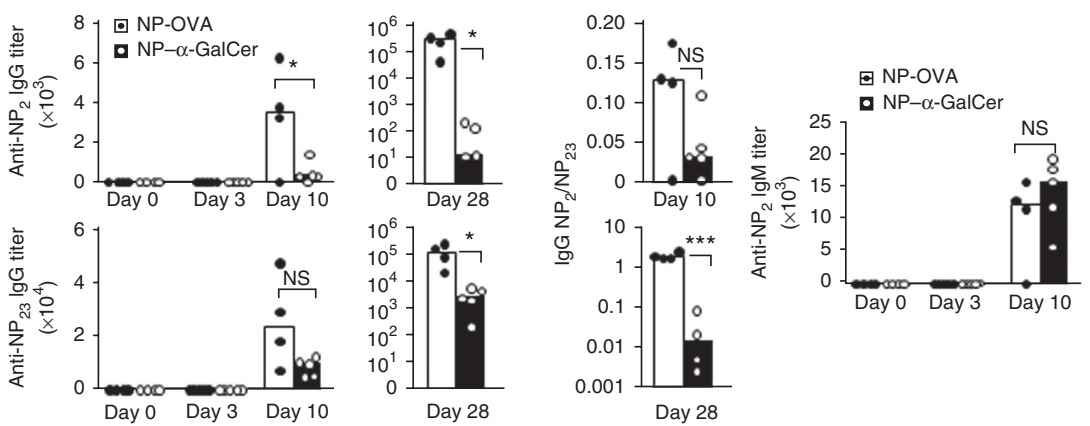

d
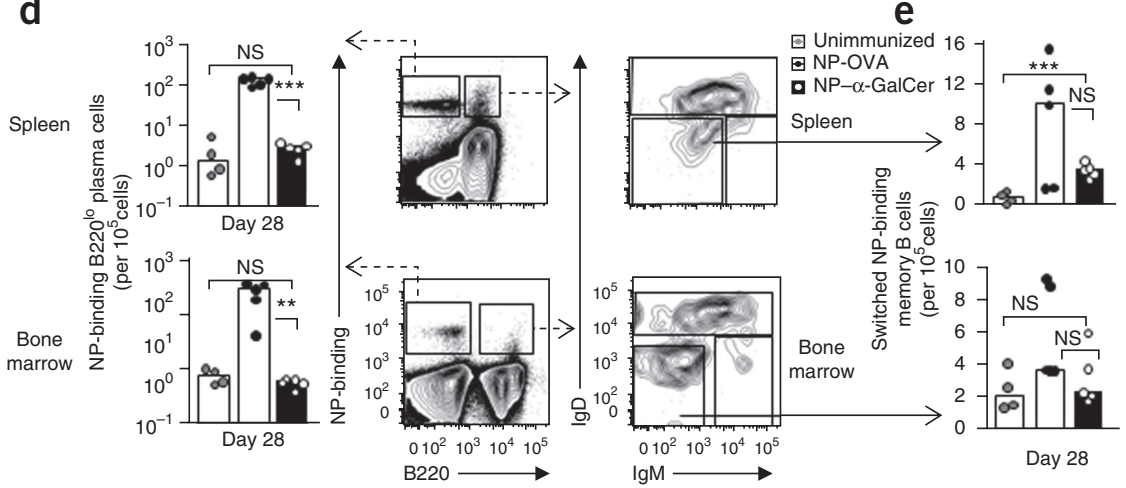

Figure $7 \mathrm{NKT}_{\mathrm{FH}}$ cell-induced germinal centers leads to limited affinity maturation. (a) Gating strategy to identify splenic CD1d- $\alpha$-GalCer tetramerpositive $\mathrm{CD}^{+}{ }^{+} \mathrm{TCR}^{\text {int }} \mathrm{NKT}$ cells from unimmunized C57BL/6 mice or mice $3 \mathrm{~d}$ after injection with NP-OVA or NP- $\alpha$-GalCer (left), and induction of $\mathrm{NKT}_{\mathrm{FH}}$ cells (PD-1 ${ }^{\text {hi }} \mathrm{CXCR} 5^{\text {hi }}$ ) in the mice at left (right). (b) Gating strategy to identify splenic NP-binding GL-7+Fas ${ }^{+}$germinal-center cells (top), and NP-binding germinal-center cells among splenocytes $0,3,10$ and $28 \mathrm{~d}$ after immunization of mice with NP-OVA or NP- $\alpha$-GalCer. (c) Titer of IgG antibody to $\mathrm{NP}_{2}-\mathrm{BSA}$ (Anti-NP 2 -BSA IgG) or to $\mathrm{NP}_{23}-\mathrm{BSA}$ (Anti-NP $23-\mathrm{BSA}$ IgG) at days $0,3,10$ and 28 after immunization of mice with NP-OVA or

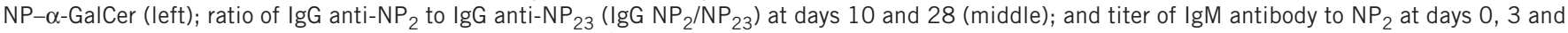
10 (right). (d) Gating strategy (right) and NP-binding B220lo plasma cells among splenic or bone marrow cells (left) from unimmunized mice or mice $28 \mathrm{~d}$ after immunization with NP-OVA or NP- $\alpha$-GalCer. (e) Switched IgD-IgM- NP-binding memory B cells among cells in $\mathrm{d}$. In graphs, each symbol represents an individual mouse; bar height indicates the median. ${ }^{*} P<0.05, * * P<0.005$ and ${ }^{* * *} P<0.0005$ (unpaired $t$-test). Data are representative of two independent experiments with four to five mice per group.

between $\mathrm{T}_{\mathrm{FH}}$ cells and $\mathrm{NKT}_{\mathrm{FH}}$ cells in phenotype, function and ability to produce IL-21, it was not unexpected to find that, as during the provision of help by $\mathrm{T}_{\mathrm{FH}}$ cells for $\mathrm{B}$ cells, IL-21 signaling was required in B cells themselves to receive NKT cell-derived help and differentiate into germinal-center B cells and plasmablasts.

Extrafollicular antibody responses occur in both $\mathrm{T}$ cell-dependent and $\mathrm{T}$ cell-independent responses. The induction of $\mathrm{T}$ cell-dependent extrafollicular responses is dependent mainly on $\mathrm{T}_{\mathrm{FH}}$ cells rather than other helper T cell subsets ${ }^{24}$; thus, it is likely that the NKT celldependent extrafollicular antibody response is also dependent on the generation of $\mathrm{NKT}_{\mathrm{FH}}$ cells. Germinal centers have been thought to be the hallmark of T cell-dependent responses; only in exceptional circumstances do $\mathrm{T}$ cell-independent germinal centers form in response to polysaccharide-based antigens ${ }^{43}$. Our results here suggested NKT cells were at least as effective as conventional $\mathrm{CD} 4^{+}$ $\mathrm{T}$ cells in the provision of cognate help for germinal-center formation.

Similar to type II T cell-independent germinal centers induced by polysaccharide (NP-Ficoll) ${ }^{43,45}$, germinal centers induced by NP- $\alpha$ GalCer had limited affinity maturation, although they seemed to survive longer than those induced by NP-Ficoll. The failure to grow in manner similar to that of germinal centers induced by NP-OVA may have been a consequence of more rapid clearance of soluble NP- $\alpha$ GalCer than of alum-precipitated protein antigens; it will be useful to investigate whether NKT cell agonists 'seen' in the context of infection with replicating bacteria are able to sustain $\mathrm{NKT}_{\mathrm{FH}}$ cell-dependent germinal centers. Alternatively, it is possible that the fewer total splenic $\mathrm{NKT}_{\mathrm{FH}}$ cells than $\mathrm{T}_{\mathrm{FH}}$ cells limits the germinal-center niches. Another possibility is that $\mathrm{NKT}_{\mathrm{FH}}$ cells can successfully induce the formation of germinal-center B cells but are not effective at selecting mutated germinal-center B cells, which may be an exclusive ability of $\mathrm{T}_{\mathrm{FH}}$ cells. This might be an effective way to limit the induction of antibodies cross-reactive with self glycolipids.

Lipid-reactive $\mathrm{B}$ cells can also receive help from $\mathrm{T}_{\mathrm{FH}}$ cells as long as the $\mathrm{B}$ cell internalizes a lipid-conjugated protein antigen through the BCR and presents the processed peptides on major histocompatibility complex class II. It is thus possible that B cells initially activated by $\mathrm{NKT}_{\mathrm{FH}}$ cells can go on to receive help from conventional $\mathrm{T}_{\mathrm{FH}}$ cells in germinal centers, leading to terminal differentiation into long-lived plasma cells and memory B cells. This may be of physiological relevance, as pathogens containing glycolipids and described to elicit NKT cell help (such as Sphingomonas species, Listeria monocytogenes and Borrelia burgdorferi) ${ }^{11}$ also contain abundant and immunogenic protein antigens. Indeed, preliminary data suggest that L. monocytogenes infection can lead to the concomitant induction of conventional $\mathrm{CD}^{+} \mathrm{T}_{\mathrm{FH}}$ cells and IL-21-producing $\mathrm{NKT}_{\mathrm{FH}}$ cells (data not shown). Alternatively, it is possible that the presence of glycolipids on microbial pathogens curtails the germinal-center response through the activation of $\mathrm{NKT}_{\mathrm{FH}}$ cells. This could explain the delayed 
productive germinal-center formation in response to infection with Salmonella typhimurium ${ }^{46}$. Further understanding of this early and innate form of $\mathrm{B}$ cell help mediated by $\mathrm{NKT}_{\mathrm{FH}}$ cells may have valuable implications for the design of more effective vaccines.

\section{METHODS}

Methods and any associated references are available in the online version of the paper at http://www.nature.com/natureimmunology/.

Note: Supplementary information is available on the Nature Immunology website.

\section{ACKNOWLEDGMENTS}

We thank the US National Institutes of Health Tetramer Core Facility for the allophycocyanin-conjugated mouse CD1d- $\alpha$-GalCer tetramer; M. Kronenberg (La Jolla Institute for Allergy and Immunology) for the baculovirus construct; P. Savage (Brigham Young University) for $\alpha$-GalCer (PBS44); M. Taniguchi (RIKEN Research Center for Allergy and Immunology) for $\mathrm{J}_{\alpha} 18$-deficient mice; $\mathrm{M}$. Townsend for tissue sectioning; X. Hu, M. Srivastava and J. Ellyard for help with some experiments; and M. Pellegrini for infection of mice with L. monocytogenes. Supported by the Sylvia and Charles Viertel Charitable Foundation (C.G.V.), the European Commission (Seventh Framework Programme of the European Commission PIEF-GA-2008-220863 to P.B.), Cancer Research UK (F.D.B. and P.B.), the Royal Society (F.D.B.), the National Health and Medical Research Council of Australia (D.I.G., C.G.V., R.B., C.S.M. and S.G.T.) and the Australian Research Council (A.K.).

\section{AUTHOR CONTRIBUTIONS}

P.-P.C. and P.B. designed, did and analyzed experiments and wrote the manuscript; J.F., C.S.M., A.P., A.K. and J.J.H. did experiments; V.C. and S.G.T. provided intellectual input; R.B., S.L.N. and R.B. provided reagents; D.I.G. provided reagents and intellectual input; and F.D.B. and C.G.V. contributed to the experimental design and analysis and wrote the manuscript.

\section{COMPETING FINANCIAL INTERESTS}

The authors declare no competing financial interests.

Published online at http://www.nature.com/natureimmunology/.

Reprints and permissions information is available online at http://www.nature.com/ reprints/index.html.

1. MacLennan, I.C. Germinal centers. Annu. Rev. Immunol. 12, 117-139 (1994).

2. Vinuesa, C.G., Tangye, S.G., Moser, B. \& Mackay, C.R. Follicular B helper T cells in antibody responses and autoimmunity. Nat. Rev. Immunol. 5, 853-865 (2005).

3. Crotty, S. Follicular helper CD4 T cells $\left(\mathrm{T}_{\mathrm{FH}}\right)$. Annu. Rev. Immunol. 29, 621-663 (2011).

4. McHeyzer-Williams, L.J., Pelletier, N., Mark, L., Fazilleau, N. \& McHeyzer-Williams, M.G. Follicular helper T cells as cognate regulators of B cell immunity. Curr. Opin. Immunol. 21, 266-273 (2009).

5. Barral, P. et al. B cell receptor-mediated uptake of $C D 1$ d-restricted antigen augments antibody responses by recruiting invariant NKT cell help in vivo. Proc. Natl. Acad. Sci. USA 105, 8345-8350 (2008).

6. Galli, G. et al. CD1d-restricted help to $B$ cells by human invariant natural killer T lymphocytes. J. Exp. Med. 197, 1051-1057 (2003).

7. Galli, G. et al. Invariant NKT cells sustain specific B cell responses and memory. Proc. Natl. Acad. Sci. USA 104, 3984-3989 (2007).

8. Leadbetter, E.A. et al. NK T cells provide lipid antigen-specific cognate help for B cells. Proc. Natl. Acad. Sci. USA 105, 8339-8344 (2008).

9. Godfrey, D.I., Stankovic, S. \& Baxter, A.G. Raising the NKT cell family. Nat. Immunol. 11, 197-206 (2010).

10. Kawano, T. et al. CD1d-restricted and TCR-mediated activation of V $\alpha 14$ NKT cells by glycosylceramides. Science 278, 1626-1629 (1997).

11. Cerundolo, V., Silk, J.D., Masri, S.H. \& Salio, M. Harnessing invariant NKT cells in vaccination strategies. Nat. Rev. Immunol. 9, 28-38 (2009).

12. Tonti, E. et al. NKT-cell help to B lymphocytes can occur independently of cognate interaction. Blood 113, 370-376 (2009).

13. Gumperz, J.E., Miyake, S., Yamamura, T. \& Brenner, M.B. Functionally distinct subsets of CD1d-restricted natural killer T cells revealed by CD1d tetramer staining. J. Exp. Med. 195, 625-636 (2002).

14. Benlagha, K., Kyin, T., Beavis, A., Teyton, L. \& Bendelac, A. A thymic precursor to the NK T cell lineage. Science 296, 553-555 (2002).

15. Pellicci, D.G. et al. A natural killer T (NKT) cell developmental pathway involving a thymus-dependent NK1.1-CD4 ${ }^{+} \mathrm{CD} 1 \mathrm{~d}$-dependent precursor stage. J. Exp. Med. 195, 835-844 (2002).
16. Terashima, A. et al. A novel subset of mouse NKT cells bearing the IL-17 receptor $\mathrm{B}$ responds to IL-25 and contributes to airway hyperreactivity. J. Exp. Med. 205 2727-2733 (2008)

17. Coquet, J.M. et al. Diverse cytokine production by NKT cell subsets and identification of an IL-17-producing CD4-NK1.1- NKT cell population. Proc. Natl. Acad. Sci. USA 105, 11287-11292 (2008).

18. Michel, M.L. et al. Identification of an IL-17-producing NK1.1 ${ }^{\text {neg }}$ iNKT cell population involved in airway neutrophilia. J. Exp. Med. 204, 995-1001 (2007).

19. Godfrey, D.I. \& Kronenberg, M. Going both ways: immune regulation via CD1ddependent NKT cells. J. Clin. Invest. 114, 1379-1388 (2004).

20. Cannons, J.L. et al. Optimal germinal center responses require a multistage T cell: B cell adhesion process involving integrins, SLAM-associated protein, and CD84. Immunity 32, 253-265 (2010).

21. Barral, P. et al. CD169 ${ }^{+}$macrophages present lipid antigens to mediate early activation of iNKT cells in lymph nodes. Nat. Immunol. 11, 303-312 (2010).

22. Gammon, G. et al. The choice of T-cell epitopes utilized on a protein antigen depends on multiple factors distant from, as well as at the determinant site. Immunol. Rev. 98, 53-73 (1987).

23. Haynes, N.M. et al. Role of CXCR5 and CCR7 in follicular Th cell positioning and appearance of a programmed cell death gene- $1^{\text {high }}$ germinal center-associated subpopulation. J. Immunol. 179, 5099-5108 (2007).

24. Lahoud, M.H. et al. Targeting antigen to mouse dendritic cells via Clec9A induces potent CD4 T cell responses biased toward a follicular helper phenotype. J. Immunol. 187, 842-850 (2011).

25. Sullivan, B.A. et al. Mechanisms for glycolipid antigen-driven cytokine polarization by Vo14i NKT cells. J. Immunol. 184, 141-153 (2010).

26. Phan, T.G. et al. B cell receptor-independent stimuli trigger immunoglobulin (Ig) class switch recombination and production of IgG autoantibodies by anergic selfreactive B cells. J. Exp. Med. 197, 845-860 (2003).

27. Crowe, N.Y. et al. Glycolipid antigen drives rapid expansion and sustained cytokine production by NK T cells. J. Immunol. 171, 4020-4027 (2003).

28. Wilson, M.T. et al. The response of natural killer T cells to glycolipid antigens is characterized by surface receptor down-modulation and expansion. Proc. Natl. Acad. Sci. USA 100, 10913-10918 (2003).

29. Kerfoot, S.M. et al. Germinal center B cell and T follicular helper cell development initiates in the interfollicular zone. Immunity 34, 947-960 (2011).

30. Johnston, R.J. et al. Bcl6 and Blimp-1 are reciprocal and antagonistic regulators of $T$ follicular helper cell differentiation. Science 325, 1006-1010 (2009).

31. Pasquier, B. et al. Defective NKT cell development in mice and humans lacking the adapter SAP, the X-linked lymphoproliferative syndrome gene product. J. Exp. Med. 201, 695-701 (2005).

32. Dent, A.L., Hu-Li, J., Paul, W.E. \& Staudt, L.M. T helper type 2 inflammatory disease in the absence of interleukin 4 and transcription factor STAT6. Proc. Natl. Acad. Sci. USA 95, 13823-13828 (1998).

33. Linterman, M.A. et al. IL-21 acts directly on B cells to regulate Bcl-6 expression and germinal center responses. J. Exp. Med. 207, 353-363 (2010).

34. Chung, Y. et al. A critical role of costimulation during intrathymic development of invariant NK T cells. J. Immunol. 180, 2276-2283 (2008).

35. Uldrich, A.P. et al. NKT cell stimulation with glycolipid antigen in vivo: costimulationdependent expansion, Bim-dependent contraction, and hyporesponsiveness to further antigenic challenge. J. Immunol. 175, 3092-3101 (2005).

36. Yabas, M. et al. ATP11C is critical for the internalization of phosphatidylserine and differentiation of B lymphocytes. Nat. Immunol. 12, 441-449 (2010).

37. Kim, P.J. et al. GATA-3 regulates the development and function of invariant NKT cells. J. Immunol. 177, 6650-6659 (2006).

38. Araki, K. et al. mTOR regulates memory CD8 T-cell differentiation. Nature 460 , 108-112 (2009).

39. Townsend, M.J. et al. T-bet regulates the terminal maturation and homeostasis of NK and Vo14i NKT cells. Immunity 20, 477-494 (2004).

40. Matsuda, J.L. et al. T-bet concomitantly controls migration, survival, and effector functions during the development of V $\alpha 14 i$ NKT cells. Blood 107, 2797-2805 (2006).

41. Egawa, T. et al. Genetic evidence supporting selection of the Vo14i NKT cell lineage from double-positive thymocyte precursors. Immunity 22, 705-716 (2005).

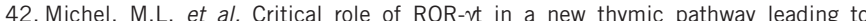
IL-17-producing invariant NKT cell differentiation. Proc. Natl. Acad. Sci. USA 105, 19845-19850 (2008).

43. Vinuesa, C.G. et al. Germinal centers without T cells. J. Exp. Med. 191, 485-494 (2000).

44. Qi, H., Cannons, J.L., Klauschen, F., Schwartzberg, P.L. \& Germain, R.N. SAPcontrolled T-B cell interactions underlie germinal centre formation. Nature 455, 764-769 (2008)

45. Toellner, K.M. et al. Low-level hypermutation in T cell-independent germinal centers compared with high mutation rates associated with $\mathrm{T}$ cell-dependent germinal centers. J. Exp. Med. 195, 383-389 (2002).

46. Cunningham, A.F. et al. Salmonella induces a switched antibody response without germinal centers that impedes the extracellular spread of infection. J. Immunol. 178, 6200-6207 (2007). 


\section{ONLINE METHODS}

Mice and immunization. MD4 and $\mathrm{V}_{\alpha}$ 14-transgenic mice were bred and maintained at the animal facility of Cancer Research UK and of the John Radcliffe Hospital, Oxford. Some C57BL/6 wild-type mice were from Charles River. Most C57BL/6 mice, all CD45.1 $1^{+} \mathrm{B} 6 \mathrm{C} 57 \mathrm{BL} / 6$ mice, $\mathrm{Il} 21^{-/-}$mice, $\mathrm{Cd} 28^{-1-}$ mice and mice with loss of CD79 $\alpha$ function $\left(C d 79 a^{\mathrm{m} 1 \mathrm{Anu} / \mathrm{m} 1 \mathrm{Anu}}\right)$ were bred and maintained in specific pathogen-free conditions at the Australian National University Bioscience Facility. J $\mathrm{J}_{\alpha} 18$-deficient mice, backcrossed ten times to the C57BL/6 background, were originally from $\mathrm{M}$. Taniguchi and were bred and maintained the Department of Microbiology and Immunology animal facility of the University of Melbourne. Wild-type, $C d 1 d^{-/-}$and $I l 21 r^{-/-} \mathrm{SW}_{\mathrm{HEL}}$ $\mathrm{CD} 45.2^{+}$mice were bred and maintained at the Garvan Institute; wild-type $\mathrm{SW}_{\mathrm{HEL}} \mathrm{CD} 45.1^{+}$mice were maintained in the Australian National University Bioscience Facility. The reporter mouse strain expressing bicistronic Il21IRES-GFP mRNA under the control of the endogenous $I l 21$ regulatory elements was bred and maintained in specific pathogen-free facilities of Walter and Eliza Hall Institute (K. Lüthje et al., unpublished data). All experiments were approved by the Australian National University Animal Ethics and Experimentation Committee, the Walter and Eliza Hall Institute Animal Experimental Ethics Committee, or the Cancer Research UK, Animal Ethics Committee and the United Kingdom Home Office.

Mice were injected intravenously or intraperitoneally with $\alpha$-GalCer ( $2 \mu \mathrm{g}$ per mouse; PBS44; provided by P. Savage) or intravenously with $\mathrm{OCH}$ ( $2 \mu \mathrm{g}$ per mouse) or $\alpha$-C-GalCer $(1 \mu \mathrm{g}$ per mouse); $\alpha$-GalCer and $\alpha$-C-GalCer were reconstituted in Tris-buffered saline containing $0.5 \%$ (vol $/ \mathrm{vol}$ ) tyloxapol. For immunization with SRBCs, mice were injected intraperitoneally with $4 \times 10^{9}$ SRBCs (IMVS Veterinary Services). For immunization with HEL-SRBC, recombinant HEL ( $100 \mu \mathrm{g} / \mathrm{ml}$; Sigma) was conjugated to SRBCs.

Liposome preparation and microsphere coating. HEL and OVA (each from Sigma) were biotinylated through the use of sulfo-NHS-LC-LC-biotin (Pierce). Biotinylated NP-BSA was from Biosearch Technologies; $\alpha$-GalCer was from Alexis Biochemical; and 1,2-dioleoyl-sn-glycero-3-phosphocholine (DOPC) and N-cap biotinyl-phosphatidylethanolamine (PE-biotin) were from Avanti Polar Lipids. For the preparation of liposomes containing DOPC and PEbiotin (at a ratio of $98 / 2(w t / w t))$ or DOPC, PE-biotin and $\alpha$-GalCer $(88 / 2 / 10$ $(\mathrm{wt} / \mathrm{wt} / \mathrm{wt})$ ), lipids were dried under argon, resuspended in a solution of $25 \mathrm{mM}$ Tris and $150 \mathrm{mM} \mathrm{NaCl}, \mathrm{pH} 7.0$, with vigorous mixing, and liposomes were obtained by cryofracture of the lipid preparation. For coating, silica microspheres (200 $\mathrm{nm}$ in diameter; Kisker) were incubated with liposomes and washed with PBS containing 1\% (vol/vol) BSA and 1\% (vol/vol) FCS (GibcoInvitrogen), followed by incubation with streptavidin (Sigma) and biotinylated HEL or OVA or NP-BSA.

Adoptive transfer and immunization. For adoptive transfer, $1 \times 10^{5} \mathrm{CD} 45.1^{+}$ or CD $45.2^{+} \mathrm{SW}_{\mathrm{HEL}} \mathrm{B}$ cells (wild-type, Cd1 $d^{-/-}$or $I l 21 r^{--}$) were injected intravenously into the lateral tail veins of recipient mice. Recipient mice were also injected with $0.1 \mu \mathrm{l}$ particulate HEL, $\alpha$-GalCer or HEL- $\alpha$-GalCer, or $2 \times 10^{8}$ SRBCs conjugated to HEL. To elicit NP-specific response, mice were injected with NP-OVA (Biosearch Technologies) precipitated in alum and NP- $\alpha$-GalCer. Alum-precipitated NP-OVA was injected together with $5 \times 10^{8}$ formalin-inactivated Bordetella pertussis.

Generation of chimeras. Recipient mice deficient in recombination-activating gene 1 were irradiated (500 rads) and then reconstituted by intravenous injection of a 50:50 mixture of $\mathrm{Bcl6}^{+/+}$fetal liver cells and Sh2d1 $\mathrm{a}^{-/-}$ bone marrow-derived hematopoietic stem cells or $B c l 6^{-l-}$ fetal liver cells and

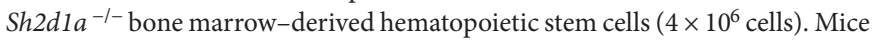
were treated with antibiotics for 4 weeks after irradiation. Experiments were done 8 weeks later to allow full reconstitution of the immune system.

Human tonsils. Human tonsils were obtained from consenting patients undergoing routine tonsillectomy at the St Vincent's Hospital (Darlinghurst, Australia) with approval from the institutional human research ethics committees.

Antibodies and staining reagents. All antibodies for flow cytometry were from BD PharMingen except Pacific Blue-conjugated antibody to mouse CD45.1
(A20; Biolegend) or CD45.2 (104; Biolegend); phycoerythrin-conjugated anti-PD-1 (J43; eBioscience); Alexa Fluor 700-conjugated anti-CD45.1 (A20; Biolegend); peridinin chlorophyll protein-cyanine 5.5-conjugated anti-TCR $\beta$ (H57-597; eBioscience); fluorescein isothiocyanate-conjugated anti-CD127 (A7R34; Biolegend); streptavidin-phycoerythrin-indotricarbocyanine (eBioscience); allophycocyanin-conjugated anti-CD45.1 (A20; eBioscience); $\mathrm{NP}_{32}$-phycoerythrin (N-5070-1; Biosearch Technologies); biotin-conjugated goat anti-rat (AffiniPure, H+L; Jackson ImmunoResearch); Alexa Fluor 647conjugated antibody to mouse BTLA (8F4; eBioscience); fluorescein isothiocyanate-conjugated antibody to human $\mathrm{V}_{\alpha} 24$ (C15; Immunotech); biotin-conjugated anti- $\mathrm{V}_{\alpha} 24$ (C15; Immunotech); phycoerythrin-conjugated anti- $\mathrm{V}_{\beta} 11$ (C21; Immunotech); and biotin-conjugated antibody to human PD-1 (polyclonal goat IgG, R\&D Systems) or BTLA (MIH26, eBioscience). The HyHEL9 monoclonal antibody to HEL was conjugated to Alexa Fluor 647 with a monoclonal antibody labeling kit (Invitrogen), and HEL was conjugated to Alexa Fluor 647 with a protein labeling kit (Invitrogen). Allophycocyanin- or phycoerythrin-conjugated CD1d- $\alpha$-GalCer tetramer was provided by the US National Institutes of Health Tetramer Core Facility or was produced in-house at the University of Melbourne through the use of a baculovirus construct originally provided by M. Kronenberg. Tetramers produced in-house were loaded with $\alpha$-GalCer (PBS44) provided by P. Savage.

Cell suspensions and flow cytometry. Suspensions of spleen and lymph node cells were prepared by sieving and gentle pipetting. Suspensions of human tonsil cells were prepared by dissection of tonsils into small pieces, followed by gentle sieving and pipetting. Debris and dead human tonsil cells were then removed by centrifugation with Ficoll-Paque PLUS (GE Healthcare BioSciences), and a further step was done for lysis of the remaining red blood cells. For surface staining, cells were maintained in the dark at $4{ }^{\circ} \mathrm{C}$ throughout. Cells were incubated for 20 min with each antibody in flow cytometry buffer (PBS with $0.002 \%$ (vol/vol) $\mathrm{NaN}_{3}$ and $0.5 \%$ (vol/vol) FCS) and were washed thoroughly with flow cytometry buffer. For staining of CXCR5, cells were incubated for $1 \mathrm{~h}$ with purified rat antibody to mouse CXCR5 (2G8; BD Pharmingen), for 30 min with biotin-conjugated AffiniPure goat anti-rat $(\mathrm{H}+\mathrm{L})$ and then for $30 \mathrm{~min}$ with streptavidin-phycoerythrin-indotricarbocyanine in the presence of normal mouse serum. Before intracellular staining of HEL-Alexa Fluor 647, cells were fixed and made permeable for $20 \mathrm{~min}$ at $4{ }^{\circ} \mathrm{C}$ with Cytofix/Cytoperm buffer (BD PharMingen) and were washed with $2 \times$ Perm/Wash buffer (BD PharMingen). For intracellular staining of NP-PE, cells were fixed for $10 \mathrm{~min}$ in $25^{\circ} \mathrm{C}$ in the dark with $4 \%$ (vol/vol) paraformaldehyde, then were washed with flow cytometry buffer with $0.2 \%$ ( $\mathrm{vol} / \mathrm{vol})$ saponin and stained in the presence of $0.2 \%$ (vol/vol) saponin. For other intracellular staining, cells were fixed and made permeable with a Mouse Regulatory T Cell Staining Kit according to the manufacturer's instructions (eBiosciences). An LSR II or FACSCanto II (BD) and FACSDiva software (BD) were used for the acquisition of flow cytometry data, and FlowJo software (TreeStar) was used for analysis.

Preparation of B cells and NKT cells. MD4 B cells were purified by negative selection from the spleen with a mouse B cell isolation kit (Miltenyi Biotec). NKT cells were enriched from the livers and spleens of $V_{\alpha} 14$-transgenic mice. Liver NKT cells were prepared by the generation of single-cell suspensions of perfused livers of naive mice. Enrichment of NKT cells was achieved by overlaying of $80 \%$ Percoll with cells resuspended in $40 \%$ Percoll. Cells were centrifuged for $25 \mathrm{~min}$ at $394 \mathrm{~g}$ and collected from the interface and, after lysis of red blood cells, further enrichment was achieved by incubation with biotinylated anti-B220 (RA3-6B2), anti-CD11c (HL3), anti-CD11b (M1/70) and anti-CD8 (53-6.7; all from BD Biosciences) followed by incubation with magnetic streptavidin beads (Invitrogen). NKT cells were stained with allophycocyanin-conjugated CD1d- $\alpha$-GalCer tetramer and accounted for $35-40 \%$ of the enriched cells.

Adoptive transfer and CFSE analysis. Purified MD4 B cells were labeled for 15 min at $37^{\circ} \mathrm{C}$ with $2 \mu \mathrm{M}$ CFSE (carboxyfluorescein diacetate succinimidyl ester; Molecular Probes) in PBS, then were washed and left in culture for $1 \mathrm{~h}$ to allow equilibration of the dye. MD4 B cells $\left(5 \times 10^{6}\right)$ were adoptively transferred by injection into the tail veins of 4 - to 6 -week- old C57BL/6 
recipient mice. After 16-20 h, recipients were immunized subcutaneously in the footpad with $1 \mu \mathrm{l}$ of the stock of particles $\left(\sim 1 \times 10^{9}\right.$ particles per microliter $)$ containing $\alpha$-GalCer and/or HEL. Then, $3 \mathrm{~d}$ after antigen injection, draining popliteal lymph nodes were collected and single-cell suspensions were stained for analysis of surface binding of HEL as described ${ }^{5}$.

Multiphoton microscopy. After enrichment, NKT cells and MD4 B cells were labeled for $15 \mathrm{~min}$ at $37^{\circ} \mathrm{C}$ with $2 \mu \mathrm{M}$ CFSE or $2 \mu \mathrm{M}$ SNARF- 1 (seminaphthorhodafluor; Molecular Probes) in PBS, then were washed and left in culture for $1 \mathrm{~h}$ to allow equilibration of the dye. Labeled MD4 B cells $\left(3 \times 10^{6}\right.$ to $4 \times 10^{6}$ ) were injected together with the same number of differently labeled $\mathrm{V}_{\alpha} 14^{+} \mathrm{T}$ cells by injection into the tail veins of 4- to 6-week-old C57BL/6 recipient mice. After 16-20 h, recipients were immunized subcutaneously in the footpad with $1 \mu \mathrm{l}$ of the stock of particles $\left(\sim 1 \times 10^{9}\right.$ particles per microliter $)$ containing HEL or HEL- $\alpha$-GalCer. Popliteal lymph nodes were removed and imaged between $24 \mathrm{~h}$ and $48 \mathrm{~h}$ after antigen injection.

Popliteal lymph nodes were prepared for multiphoton imaging as reported ${ }^{21}$. Lymph nodes were cemented through the hylum to the base of a glassbottomed $35-\mathrm{mm}$ culture dish by the veterinary topical tissue adhesive Nexaband (Abbott Laboratories) and were continuously perfused with warmed $\left(37^{\circ} \mathrm{C}\right)$ RPMI-1640 medium without phenol red (Gibco-Invitrogen) and bubbled with carbogen $\left(95 \% \mathrm{O}_{2}\right.$ and $\left.5 \% \mathrm{CO}_{2}\right)$. The system was set up inside the environmental chamber that covered the microscope, and a temperature of $37^{\circ} \mathrm{C}$ was maintained throughout the imaging session. Images were acquired through the capsule of the lymph node with an upright multiphoton microscope (Fluoview FV1000 MPE2 Twin system; Olympus) with a waterimmersion $25 \times$ objective with a numerical aperture of 1.05 (Olympus XLPLNWMP) and a pulsed Ti:sapphire laser (MaiTai HP DeepSee; Spectra Physics) tuned to provide an excitation wavelength of $800 \mathrm{~nm}$. The DeepSee unit attached to the laser introduces a 'pre-chirp' to the pulse, which compensates for the group-velocity dispersion of the optical system. This allows short laser pulses ( 110 fs) of the sample, which results in a higher peak power with a moderate average laser power. For four-dimensional imaging $(x, y, z$ and time), stacks of 11-20 square $x y$ planes spanning $508 \mu \mathrm{m} \times 508 \mu \mathrm{m}$ with $5-\mu \mathrm{m} z$ spacing were acquired over $20-30 \mathrm{~min}$ (30-40 time points). Emission wavelengths were detected through band-pass filters of 515-560 nm (CFSE) and 590-650 nm (SNARF-1). Sequences of image stacks were transformed into volume-rendered four-dimensional movies and were analyzed with Imaris $6.3 \times 64$ software (Bitplane). Adobe Photoshop CS3.0 and ImageJ were used for annotation and final movie compilation.
Imaris $6.3 \times 64$ software (Bitplane) was used for analysis of four-dimensional multiphoton movies. The average speed of individual cells was calculated as path length over time $(\mu \mathrm{m} / \mathrm{min})$.

Purification of NKT cells and adoptive transfer. NKT cells were purified by sorting of the splenoctyes of $\mathrm{V}_{\alpha} 14$-transgenic mice with CD1d- $\alpha$-GalCer tetramers as described ${ }^{21}$. Purified NKT cells ( $>97 \%$ positive for the CD1d- $\alpha$ GalCer tetramer; $3 \times 10^{6}$ to $4 \times 10^{6}$ cells) were injected into the lateral tail veins of 4 - to 6-week-old CD $45.1^{+}$congenic recipient mice.

Immunofluorescence. Spleen sections (10 $\mathrm{mm}$ in thickness) were fixed in icecold acetone and blocked with $1 \%(\mathrm{vol} / \mathrm{vol}) \mathrm{BSA}$ and $10 \%(\mathrm{vol} / \mathrm{vol})$ goat serum in PBS before incubation with Alexa Fluor 488-conjugated antibody to mouse B220 (RA3-6B2; BD Biosciences), phycoerythrin-conjugated anti-TCR $\beta$ (H57-597; eBioscience), phycoerythrin-conjugated anti-PD-1 (RMP1-30; Biolegend) and allophycocyanin-conjugated anti-CD45.2 (104; Biolegend). Alternatively, spleen sections were incubated with fluorescein isothiocyanate-conjugated antibody to mouse IgD (11-26c.2a; BD Biosciences), allophycocyanin-conjugated antiCD45.2 (104; Biolegend) and peanut agglutinin-biotin (Vector Laboratories), followed by streptavidin-Alexa Fluor 546 (S-11225; Molecular Probes). An Axiovert LSM 510-META inverted microscope (Zeiss) was used for imaging.

Enzyme-linked immunosorbent assay. Serum titers of HEL-specific and NPspecific antibodies were quantified by enzyme-linked immunosorbent assay. For quantification of HEL-specific IgG, 96-well plates were coated overnight with HEL protein or NP $(5 \mu \mathrm{g} / \mathrm{ml})$ in $0.05 \mathrm{M}$ carbonate buffer $\left(\mathrm{Na}_{2} \mathrm{CO}_{3}\right.$ and $\mathrm{NaHCO}_{3}, \mathrm{pH} 9.6$ ) and were subsequently blocked for $1.5 \mathrm{~h}$ at $37^{\circ} \mathrm{C}$ with $1 \%$ ( $\mathrm{vol} / \mathrm{vol}$ ) BSA in PBS. Serum was serially diluted with $1 \%$ (vol/vol) BSA and $0.05 \%$ (vol/vol) Tween-20 in PBS and was incubated for $1 \mathrm{~h}$ at $37^{\circ} \mathrm{C}$. After washing, antigen-specific antibodies were detected with alkaline phosphataseconjugated goat antibody to mouse IgG (1030-04; Southern Biotechnology Associates) or to mouse IgM (1021-04; Southern Biotechnology Associates). Bound antibodies were detected with 4-nitrophenyl phosphate disodium salt hexahydrate in glycine buffer. Plates were read at $405 \mathrm{~nm}$ (DL 405-650) with a Thermomax Microplate Reader (Molecular Devices).

Statistical analyses. All data were analyzed with the nonparametric MannWhitney U-test or unpaired $t$-test, except fetal liver chimera experiments, which were analyzed with the paired $t$-test. Prism software (version 5; GraphPad Software) was used for all statistical analyses. 